\title{
Ganglioside GD2 Enhances the Malignant Phenotypes of Melanoma Cells by Cooperating with Integrins
}

\author{
Farhana Yesmin ${ }^{1,2}$, Robiul H. Bhuiyan ${ }^{1}{ }^{10}$, Yuhsuke Ohmi ${ }^{3}$, Satoko Yamamoto ${ }^{1}$, Kei Kaneko ${ }^{1}$, Yuki Ohkawa ${ }^{1,4}$, \\ Pu Zhang ${ }^{1,2}$, Kazunori Hamamura ${ }^{5}{ }^{\infty}$, Nai-Kong V. Cheung ${ }^{6}{ }^{(D}$, Norihiro Kotani ${ }^{7}$, Koichi Honke ${ }^{8} \mathbb{D}^{-}$, \\ Tetsuya Okajima ${ }^{2} \mathbb{D}$, Mariko Kambe ${ }^{1}$, Orie Tajima ${ }^{1}$, Keiko Furukawa ${ }^{1}$ and Koichi Furukawa ${ }^{1,2, *(D)}$
}

1 Department of Biomedical Sciences, Chubu University College of Life and Health Sciences, Kasugai 487-8501, Japan; farhana7779@gmail.com (F.Y.); biochemistrobi79@gmail.com (R.H.B.); satoyama@isc.chubu.ac.jp (S.Y.); ikekoneka@isc.chubu.ac.jp (K.K.); yuki34@mc.pref.osaka.jp (Y.O.); apor0825@yahoo.co.jp (P.Z.); kambem@isc.chubu.ac.jp (M.K.); oriet@isc.chubu.ac.jp (O.T.); keikofu@isc.chubu.ac.jp (K.F.)

2 Department of Molecular Biochemistry, Nagoya University Graduate School of Medicine, Nagoya 466-0065, Japan; tokajima@med.nagoya-u.ac.jp

3 Department of Medical Technology, Chubu University College of Life and Health Sciences, Kasugai 487-8501, Japan; ooumi82@isc.chubu.ac.jp

4 Department of Glyco-Oncology and Medical Biochemistry, Osaka International Cancer Institute, Osaka 541-8567, Japan

5 Department of Pharmacology, Aichi Gakuin University School of Dentistry, Nagoya 464-8650, Japan; hamak@dpc.agu.ac.jp

6 Memorial Sloan-Kettering Cancer Center, New York, NY 10065, USA; cheungn@mskcc.org

7 Department of Biochemistry, Saitama Medical University, Saitama 350-0495, Japan; kotani@saitama-med.ac.jp

8 Department of Biochemistry, Kochi University School of Medicine, Nangoku 783-8505, Japan; khonke@kochi-u.ac.jp

check for

Citation: Yesmin, F.; Bhuiyan, R.H.; Ohmi, Y.; Yamamoto, S.; Kaneko, K. Ohkawa, Y.; Zhang, P.; Hamamura,

K.; Cheung, N.-K.V.; Kotani, N.; et al. Ganglioside GD2 Enhances the Malignant Phenotypes of Melanoma Cells by Cooperating with Integrins. Int. J. Mol. Sci. 2022, 23, 423. https:// doi.org/10.3390/ijms23010423

Academic Editor: Cheorl-Ho Kim

Received: 30 October 2021

Accepted: 28 December 2021

Published: 31 December 2021

Publisher's Note: MDPI stays neutral with regard to jurisdictional claims in published maps and institutional affiliations.

Copyright: (C) 2021 by the authors. Licensee MDPI, Basel, Switzerland. This article is an open access article distributed under the terms and conditions of the Creative Commons Attribution (CC BY) license (https:// creativecommons.org/licenses/by/ $4.0 /)$.
* Correspondence: koichi@isc.chubu.ac.jp; Tel.: +81-568-51-9512

Abstract: Gangliosides have been considered to modulate cell signals in the microdomain of the cell membrane, lipid/rafts, or glycolipid-enriched microdomain/rafts (GEM/rafts). In particular, cancer-associated gangliosides were reported to enhance the malignant properties of cancer cells. In fact, GD2-positive (GD2+) cells showed increased proliferation, invasion, and adhesion, compared with GD2-negative (GD2-) cells. However, the precise mechanisms by which gangliosides regulate cell signaling in GEM/rafts are not well understood. In order to analyze the roles of ganglioside GD2 in the malignant properties of melanoma cells, we searched for GD2-associating molecules on the cell membrane using the enzyme-mediated activation of radical sources combined with mass spectrometry, and integrin $\beta 1$ was identified as a representative GD2-associating molecule. Then, we showed the physical association of GD2 and integrin $\beta 1$ by immunoprecipitation/immunoblotting. Close localization was also shown by immuno-cytostaining and the proximity ligation assay. During cell adhesion, GD2+ cells showed multiple phospho-tyrosine bands, i.e., the epithelial growth factor receptor and focal adhesion kinase. The knockdown of integrin $\beta 1$ revealed that the increased malignant phenotypes in GD2+ cells were clearly cancelled. Furthermore, the phosphor-tyrosine bands detected during the adhesion of GD2+ cells almost completely disappeared after the knockdown of integrin $\beta 1$. Finally, immunoblotting to examine the intracellular distribution of integrins during cell adhesion revealed that large amounts of integrin $\beta 1$ were localized in GEM/raft fractions in GD2+ cells before and just after cell adhesion, with the majority being localized in the non-raft fractions in GD2 - cells. All these results suggest that GD2 and integrin $\beta 1$ cooperate in GEM/rafts, leading to enhanced malignant phenotypes of melanomas.

Keywords: ganglioside; cancer-associated antigen; integrin; GEM/rafts; melanoma 


\section{Introduction}

Gangliosides are sialic acid-containing glycosphingolipids, and they are expressed in almost all the cells and tissues of vertebrates [1]. In particular, complex gangliosides are commonly enriched in the nervous tissues of many animals in common, and have been considered to play important roles in the development and function of the nervous system [2]. On the other hand, some gangliosides were reported to be expressed in particular cancer cells and tissues, and so they have been considered to be cancer-associated carbohydrate antigens [3,4]. Among them, the gangliosides GD3 and GD2 have been used as markers for neuroectoderm-derived cancers, and also as targets of immunotherapy, such as antibody therapy [5-7].

Since the cDNAs of ganglioside synthetic enzymes were isolated, it became possible to investigate the roles of gangliosides in various cells and tissues [8]. In particular, the genetic engineering of glycosyltransferase genes in cultured cells and experimental animals have enabled us to clarify significant roles of gangliosides, and their mechanisms in development and carcinogenesis [9].

Although it became possible to compare the phenotypic changes of glyco-remodeling cells and animals, the mechanisms by which gangliosides modulate the phenotypes and cell signals have remained unclear. This is because glycosphingolipids are expressed on the outer layer of the lipid bilayer membrane [10], and it can be difficult to mediate cell signals that are introduced via the cell membrane. The novel approach of EMARS/MS (enzymemediated activation of radical sources/mass spectrometry) has led to a breakthrough in this issue. EMARS/MS was developed by Kotani and Honke [11], and has been verified to be a powerful method to identify interacting molecules with some target antigens on the cell surface [12]. Since we use living cells to analyze events on the cell surface, corresponding to the size of membrane microdomains, this method uses no special equipment and is applicable for a comprehensive analysis of clustering molecules with particular targets [11] We have reported the interesting molecular associations of gangliosides with newly-defined membrane molecules in melanomas [13] and gliomas [14]. Thus, the functional analysis of cancer-associated glycolipids is entering a new era [15].

Among the cancer-associated glycolipids, GD2 is specifically important because of its key roles in the metastasis of melanomas [16], as a marker of cancer stem cells for breast cancers [17] and triple-negative breast cancers [18], and as targets of novel immune therapy for neuroectoderm-derived cancers [19] and other cancers, too [20].

In this study, we identify the membrane molecules interacting with ganglioside GD2 on the surface of human melanoma cells using EMARS/MS, and integrins were identified as representative molecules to associate with GD2. Furthermore, not only is there a close connection between GD2 and integrins, but the study also elucidated their marked cooperation in the augmentation of cancer phenotypes, particularly in cell adhesion, proliferation, and invasion.

\section{Results}

\subsection{Establishment and Confirmation of GD2+ Melanoma Cell Lines}

Using a subline of the human melanoma cell line SK-MEL-28 (N1) [21], GD2-positive lines, S6 and S2, were established based on the synthetic pathway (Figure 1A), as previously described [22]. We selected strong GD2-expressing, but not GD3-expressing, lines in order to clearly identify the specific function of GD2. The expression pattern of GD2 and GD3 is shown in Figure 1B. The detection of GD2 by mAb 3F8 is shown in Supplementary Figure S1. Negative control lines, V4 and V9, were also established, which were neo-resistant but not expressing GD2 or GD3. The expression of GD2 was confirmed by immunocytochemistry, as shown in Figure 1C. 
A

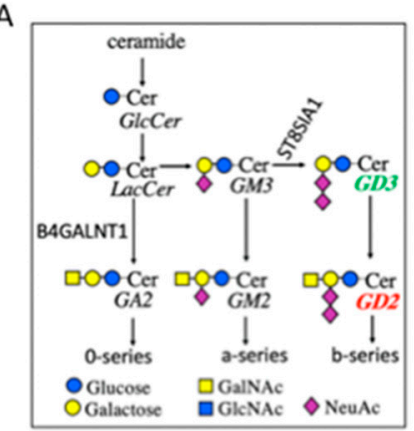

$C_{\text {mab }}$

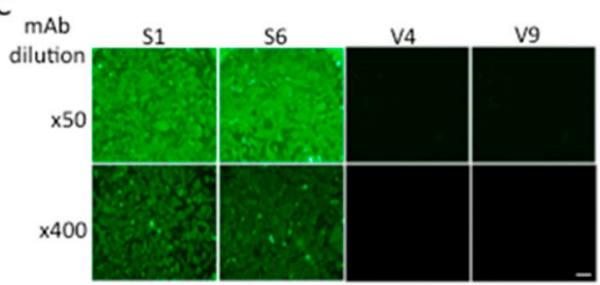

B

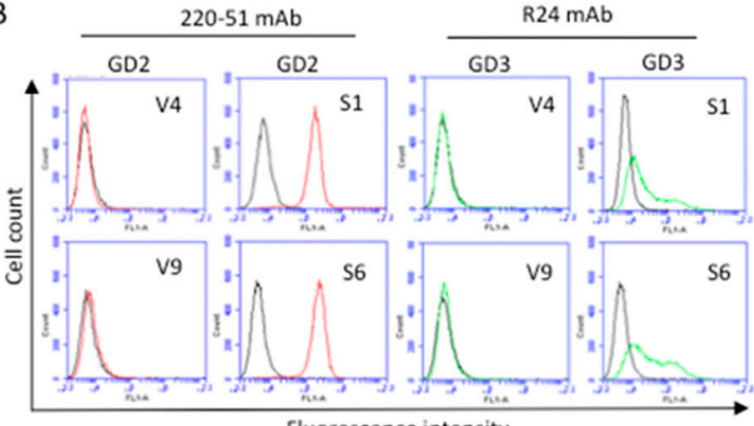

Fluorescence intensity

Figure 1. Establishment of cell lines expressing ganglioside GD2. (A) Biosynthetic pathway of gangliosides and their synthetic enzymes. (B) Expressions of gangliosides GD2 and GD3 in GD2+ (S1 and S6) and GD2- (V4 and V9) cells were analyzed by flow cytometry, using anti-GD2 and anti-GD3 mAbs. (C) Immunofluorescence images of the expression of GD2 in S1 and S6 cells using purified anti-GD2 mAb 220-51 at 4.5 and $36 \mu \mathrm{g} / \mathrm{mL}$, and an FITC anti-mouse IgG 2nd antibody. Scale bar: $50 \mu \mathrm{m}$.

\subsection{GD2 Expression Resulted in the Increased Malignant Properties of Melanomas}

Cell proliferation was analyzed using GD2+ and GD2- cells by MTT. As shown in Figure 2A, S1 and S6 showed a higher proliferation activity than V4 and V9 with significance $\left({ }^{*} p<0.05\right)$. When the invasion activity was compared between GD2+ and GD2- cells, the GD2+ cells showed greater invasion than GD2 - cells (Figure 2B). In this experiment, the upper chamber of inserts was coated with Matrigel, and FCS was added to the lower chamber. Giemsa-stained cells on the reverse side of the membrane are shown in Figure 2C. In order to examine the cell adhesion activity, the RT-CES system was used. After plating cells in collagen I-precoated microplates, the cell index was monitored for $24 \mathrm{~h}$. The GD2+ cells showed stronger adhesion activity than the GD2- cells (Figure 2D).

\subsection{Anti-GD2 Monoclonal Antibody Suppressed the Increased Malignant Properties of GD2+ Cells}

In order to clarify the involvement of GD2 in the malignant properties, anti-GD2 monoclonal antibodies (mAbs) were added during the measurement of cell growth and adhesion. To examine the effects of anti-GD2 mAb on cell growth, the MTT assay was performed using GD2+ S1 and GD2- V4 cells. Purified anti-GD2 mAbs 220-51 were added to each well at 72,18 , and $4.5 \mu \mathrm{g} / \mathrm{mL}$ for days $0-5$. Anti-GD2 mAb-treated GD2+ cells showed significant growth suppression with anti-GD2 $\mathrm{mAb}$ at 72 and $18 \mu \mathrm{g} / \mathrm{mL}$, compared with non-treated cells (Figure 3A, left). However, GD2- cells did not show significant differences between treated and non-treated cells (Figure 3A, right).

The effects of treatment with anti-GD2 mAb 220-51 on cell adhesion were analyzed by the RT-CES system using GD2+ and GD2- cells in collagen I-precoated microplates. When anti-GD2 Ab 220-51 was added to GD2+ cells at $0.5 \mathrm{~h}$ (Figure 3B, left) after starting, cell adhesion was markedly suppressed for $\sim 12 \mathrm{~h}$, but gradually recovered thereafter until $24 \mathrm{~h}$. When the antibody was added at or $3.0 \mathrm{~h}$ (Figure 3C, left) after starting, cell adhesion was stably suppressed from $0.5 \mathrm{~h}$ to $24 \mathrm{~h}$ during the observation. On the other hand, when GD2 - cells were treated by anti-GD2 $\mathrm{mAb}$, there were no significant differences between the $\mathrm{mAb}$-treated and -non-treated cells (Figure $3 \mathrm{~A}, \mathrm{~B}$, right). Treatment with purified antiGD2 mAb 3F8 showed essentially similar results for GD2+ and GD2 - cells, respectively 
(Supplementary Figure S2, left and right). Thus, anti-GD2 mAbs strongly suppressed cell adhesion only for GD2+ cells.

\subsection{Identification of Integrin $B 1$ as A GD2-Associating Molecule with EMARS/MS}

EMARS (Figure 4A) was performed with GD2+ S1 cells using purified mouse antiGD2 mAb 220-51. The FITC-labeled molecules were immunoprecipitated with a rabbit anti-FITC antibody, and detected by immunoblotting with a goat anti-FITC antibody, as shown in Figure 4B. In the results of the MS analysis, there were more than 30 molecules detected, as listed in Supplementary Table S1. Among them, integrin $\beta 1$ was defined as a cell surface molecule detected only in mAb-treated cells, possibly associated with GD2. Among the 13 molecules defined, only integrin $\beta 1$ was a definite membrane molecule. Detailed procedures for LC-MS are described in the Supplementary information. The detection of integrin $\beta 1$ by MS is also summarized in Supplementary Figure S3.

A

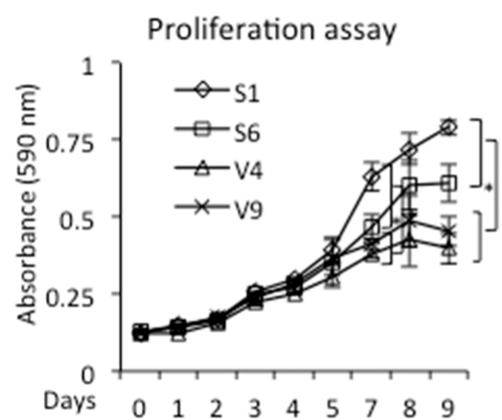

C

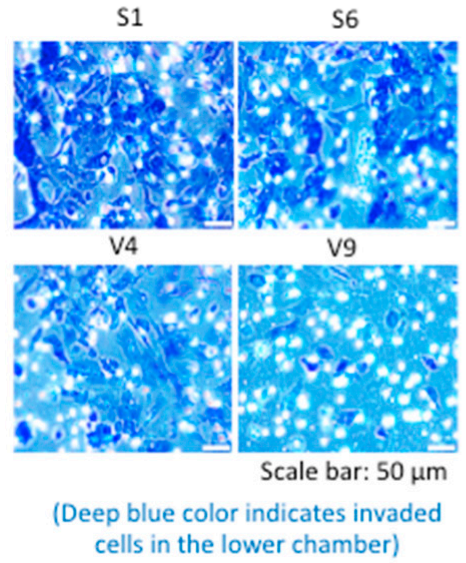

B

Invasion assay
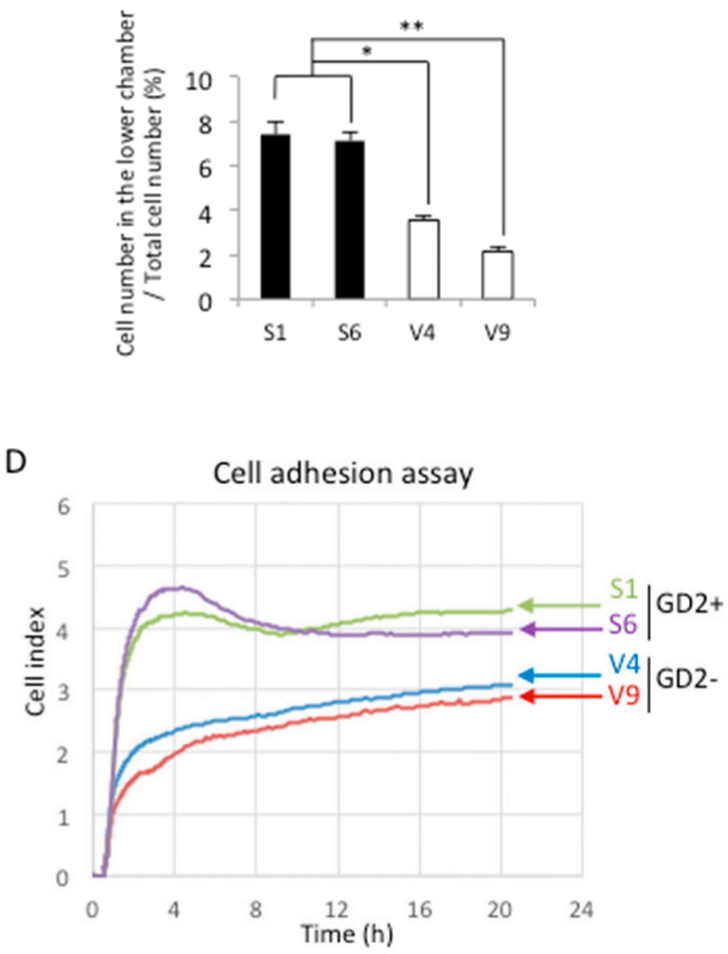

Figure 2. GD2+ cells showed increased proliferation, invasion, and cell adhesion. (A) Proliferation was analyzed using GD2+ and GD2 - cells by the MTT assay. Cells were seeded and MTT solution was added and incubated on each day, as indicated. Absorbance was measured at 590/620 nm and relative absorbance was plotted. MTT assay was performed in triplicates. The means $\pm \mathrm{SD}$ are presented, and analyzed using the two-way ANOVA with a Tukey post-hoc test between V-series vs. S-series cell lines. ${ }^{*} p<0.05$. (B) Invasion activity was analyzed using GD2+ cells and GD2- cells with cell culture inserts. After $24 \mathrm{~h}$ of incubation, cells that invaded the lower chamber were stained with Giemsa, and the number was counted under a microscope. The invasion assay was performed in triplicates. The means \pm SD are presented and analyzed using Student's $t$-test. ${ }^{*} p<0.05$ and ** $p<0.01$. (C) Microscopic images of invaded cells are shown. Scale bar: $50 \mu \mathrm{m}$. (D), cell adhesion was analyzed by the RT-CES system using GD2+ and GD2- cells in collagen I-precoated plates. 
A
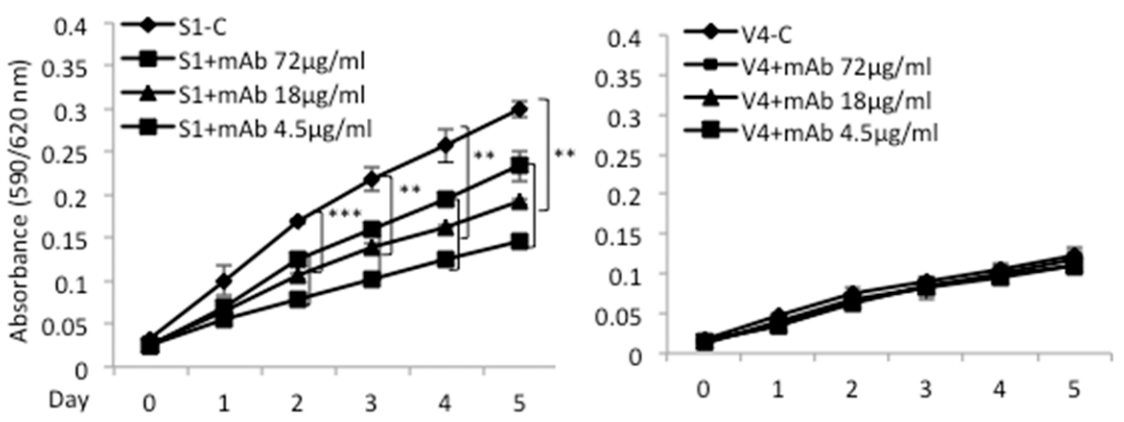

B

mAb 220-51 added at $0.5 \mathrm{~h}$

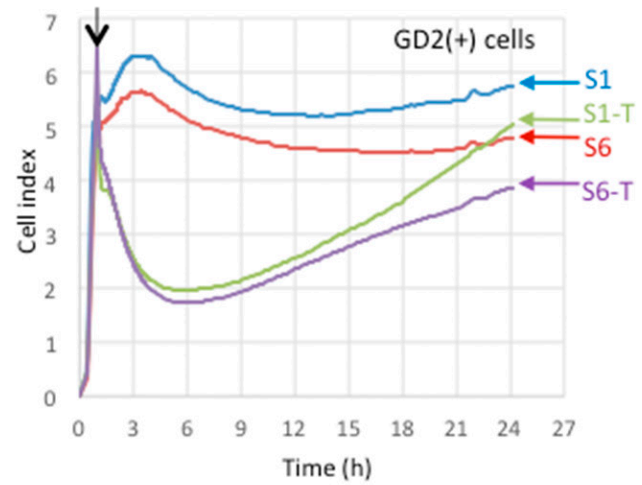

mAb $220-51$ added at $0.5 \mathrm{~h}$

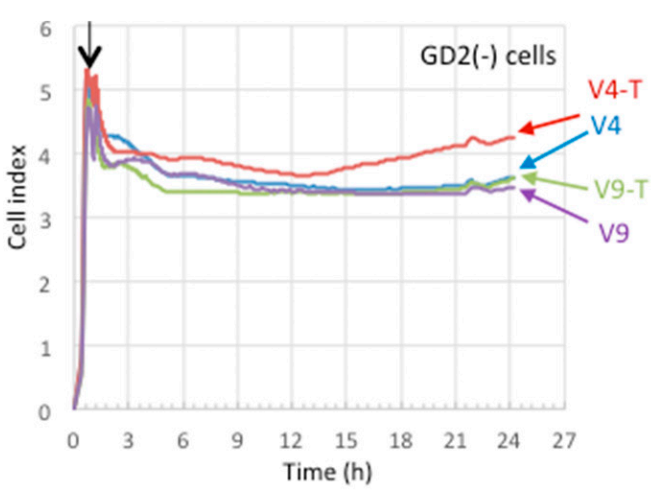

C
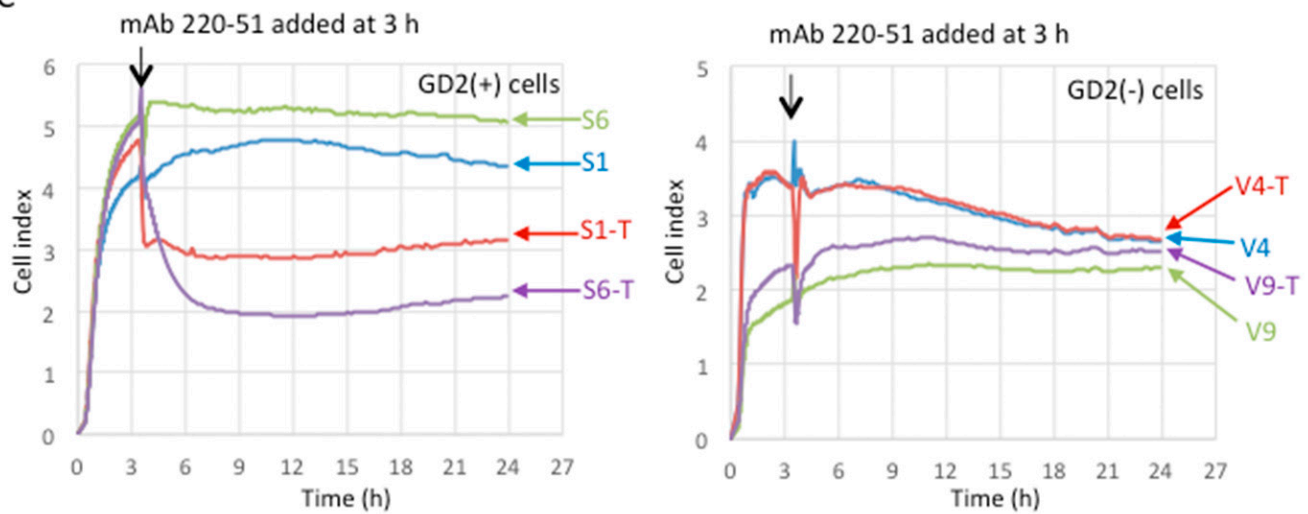

Figure 3. Effects of anti-GD2 mAbs on cell proliferation and adhesion of GD2+ cells. (A) Proliferation was analyzed by the MTT assay using GD2+ S1 and GD2- V4 cells. Cells were seeded in each well, and purified anti-GD2 mAbs 220-51 were added at 72, 18, and $4.5 \mu \mathrm{g} / \mathrm{mL}$. The MTT solution was added and incubated on each day as indicated. Absorbance was measured at 590/620 nm. The experiment was performed in triplicates (and the mean \pm SD are presented) and analyzed by two-way ANOVA with Tukey post-hoc test between control (S1-C or V4-C) vs. anti-GD2 treated cell lines (S1+mAbs or V4+mAbs). ${ }^{* * *} p<0.005$ and ${ }^{* *} p<0.01$. (B,C) Effects of treatment with anti-GD2 $\mathrm{mAb} 220-51$ on cell adhesion were analyzed by the RT-CES system, using GD2+ and GD2- cells in collagen I-precoated microplates. Cells were seeded in the plates containing $200 \mu \mathrm{L}$ of culture medium. Purified anti-GD2 antibody (220-51), $72 \mu \mathrm{g} / 200 \mu \mathrm{L}$, was added to the wells at $0.5 \mathrm{~h}$ (B) and $3.0 \mathrm{~h}(\mathrm{C})$, after starting. Antibody-treated cells are indicated as ' $\mathrm{T}$ '. 
A

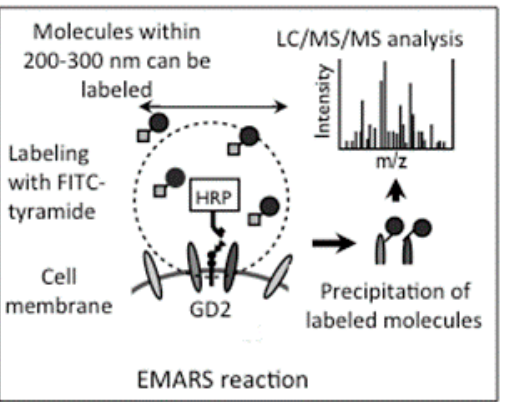

B

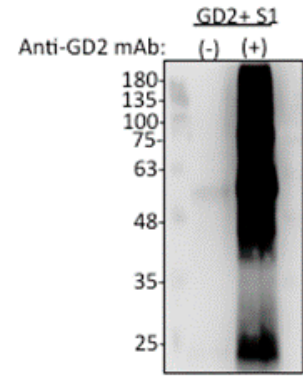

Figure 4. Identification of glycolipid-associated molecules by EMARS/MS. (A) A scheme of the EMARS/MS approach. EMARS was performed using GD2+ S1 cells, anti-GD2 mAb 220-51, and HRP-conjugated anti-mouse IgG. (B) Western blotting of EMARS reaction products. FITC-labeled molecules were immunoprecipitated and subsequently immunoblotted with anti-FITC antibodies. Bands were visualized using ImmunoStar ${ }^{\mathrm{TM}}$ LD detection kits and analyzed by Imager LI-COR ${ }^{\mathrm{TM}}$.

Cell surface expression and mRNA expression levels of integrin $\beta 1$ in GD2+ and GD2- cells were analyzed by flow cytometry using anti-integrin $\beta 1 \mathrm{mAb}$ and RT-qPCR, respectively (Figure 5A,B). Both the surface expression and mRNA of integrin $\beta 1$ showed almost equivalent levels between GD2+ and GD2- cells. The expression of integrin $\beta 1$ as well as GD2 was analyzed by immunoblotting, showing similar protein levels of integrin $\beta 1$ in all samples (Figure 5(Ca)). The binding of ganglioside GD2 and integrin $\beta 1$ was analyzed by immunoprecipitation and subsequent immunoblotting using GD2+ and GD2- clones. Cell lysates from GD2+ and GD2- cells were used for immunoprecipitation with rabbit anti-integrin $\beta 1$ antibodies, and the immunoprecipites were immunoblotted separately with mouse anti-GD2 mAb or mouse anti-integrin $\beta 1 \mathrm{mAb}$. We observed GD2+ (S1 and S6) cells and integrin $\beta 1$ in the same lanes, indicating that integrin $\beta 1$ and GD2 were associated on the cell membrane (Figure 5(Cb)).
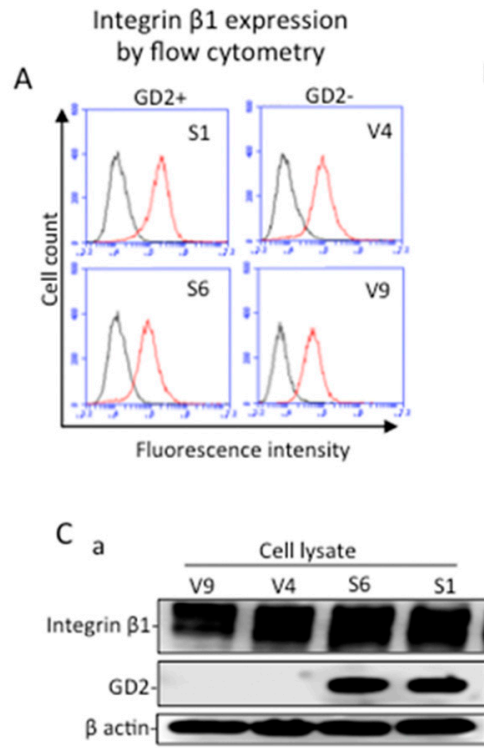

mRNA expression of integrin $\beta 1$ by RT-qPCR

B
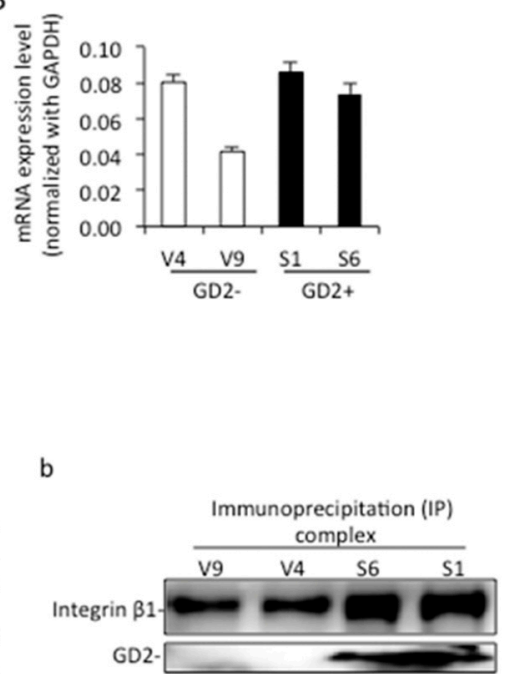

Figure 5. Physical association of GD2 and integrin $\beta 1$. (A) Cell surface expressions of integrin $\beta 1$ in GD2+ and GD2 - cells were analyzed by flow cytometry using anti-integrin $\beta 1 \mathrm{mAb}$. (B) The mRNA expression of integrin $\beta 1$ was analyzed by qRT-PCR using GD2+ and GD2- cells. The experiment was performed in triplicates and the mean \pm SD are presented. (Ca) Expressions of integrin $\beta 1$ as well as GD2 were analyzed by Western immunoblotting. GD2 and integrin $\beta 1$ were detected separately with anti-GD2 $\mathrm{mAb}$ and anti-integrin $\beta 1 \mathrm{mAb}$. $(\mathbf{C b})$ The binding of ganglioside GD2 and integrin $\beta 1$ was analyzed by immunoprecipitation with rabbit anti-integrin $\beta 1$ antibodies, and subsequent immunoblotting with anti-integrin $\beta 1 \mathrm{mAb}$ or anti-GD2 mAb. 


\subsection{Colocalization and Close Association of GD2 and Integrins as Shown in Image Analyses}

Colocalization of GD2 and integrin $\beta 1$ on the cell surface was examined by immunocytochemistry, using GD2+ S1 and S6 cells (Figure 6A). The majority of GD2 (red) was colocalized with integrin $\beta 1$ (Figure 6A, right). The interaction between GD2 and integrin $\beta 1$ was analyzed by PLA. As shown in Figure $6 \mathrm{~B}$, after fixation, GD2+ and GD2- cells were incubated with anti-GD2 and anti-integrin $\beta 1 \mathrm{mAbs}$. Then, Duolink in situ PLA probes anti-mouse PLUS and anti-rabbit MINUS were added and incubated. After the addition of a ligation-ligase solution, an amplification reaction was carried out. Under a confocal microscope, amplification products were detected as red membrane staining patterns in GD2+ cells (Figure 6B). These results suggest that GD2 and integrins cluster on the cell surface.

\section{A}

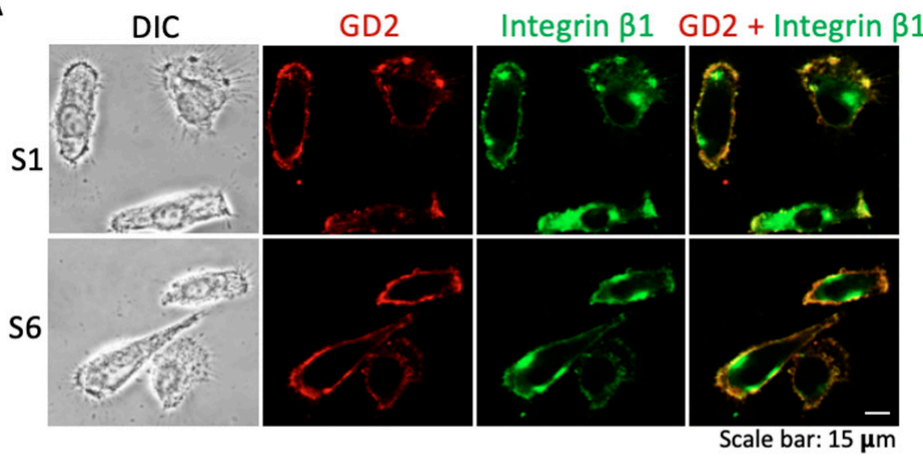

B

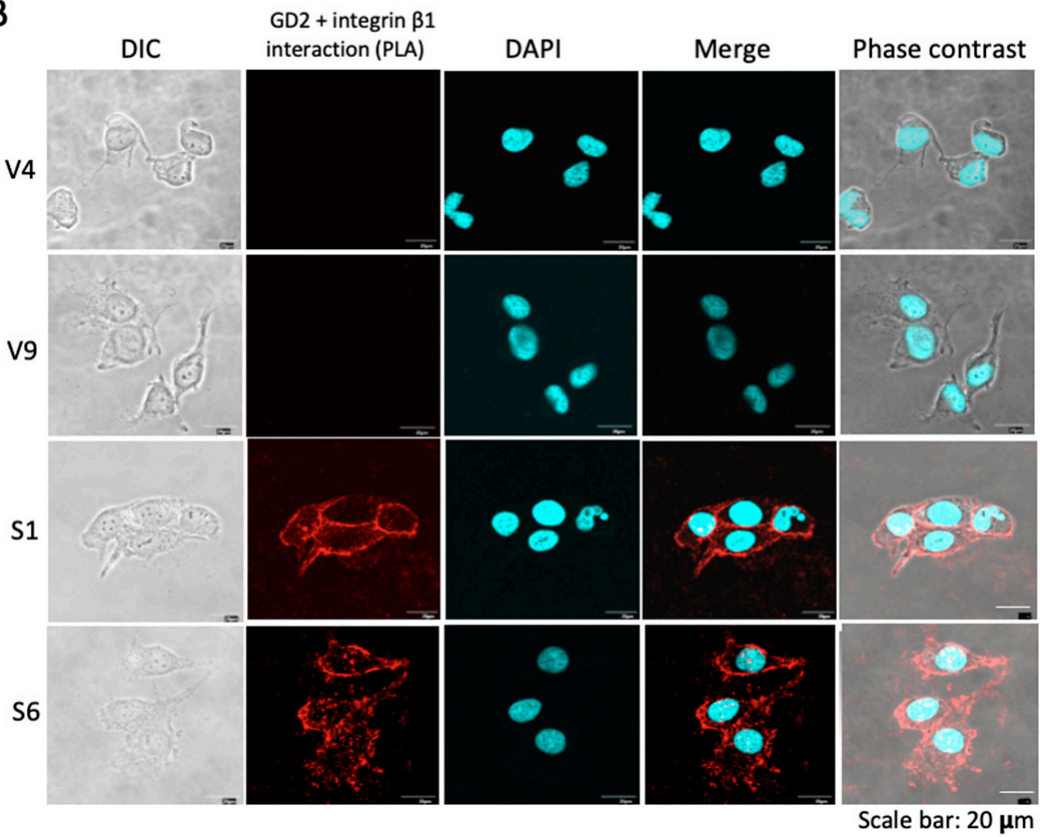

Figure 6. Colocalization of GD2 and integrin $\beta 1$. (A) Cell surface localization of GD2 and integrin $\beta 1$ was examined by immunocytochemistry using GD2+ cells. After fixation and permeabilization, cells were stained with mouse anti-GD2 $\mathrm{mAb}$ and rabbit anti-integrin $\beta 1 \mathrm{mAb}$. Then, cells were incubated with an Alexa 568-conjugated goat anti-mouse IgG antibody and an Alexa 488-conjugated donkey anti-rabbit IgG antibody. Microscopic visualization was performed using a confocal microscope. The green color indicates integrin $\beta 1$ and the red color indicates GD2. Scale bar $=15 \mu \mathrm{m}$. (B) Association between GD2 and integrin $\beta 1$ was analyzed by PLA. GD2+ and GD2- cells were incubated with anti-GD2 and anti-integrin $\beta 1 \mathrm{mAb}$. Duolink ${ }^{\mathrm{TM}}$ in situ PLA probes anti-mouse PLUS and anti-rabbit MINUS were added, then a ligation-ligase solution was added. Finally, an amplification reaction was carried out. Cells were visualized under a confocal microscope. Scale bar $=20 \mu \mathrm{m}$. 
2.6. Increased Cell Signals in GD2+ Cells as Shown by Tyrosine-Phosphorylated Proteins during Cell Adhesion to Collagen I

Cell signals were analyzed by immunoblotting with anti-phosphotyrosine mAb PY20. As shown in the diagram in Figure 7A, cells in the plain DMEM were rotated for $1 \mathrm{~h}$ after trypsinization, and added to collagen I-precoated plates. After incubation, as indicated, the cell lysates were analyzed by immunoblotting. As shown in Figure 7B, mainly 3 bands at 180,130 , and $100 \mathrm{kDa}$ were strongly detected in GD2+ cell-derived samples. The identification of these bands was performed by MS, revealing them to be EGFR and FAK (upper two bands). Detailed data of MS analysis to define these molecules are shown in Supplementary Figure S4.

A

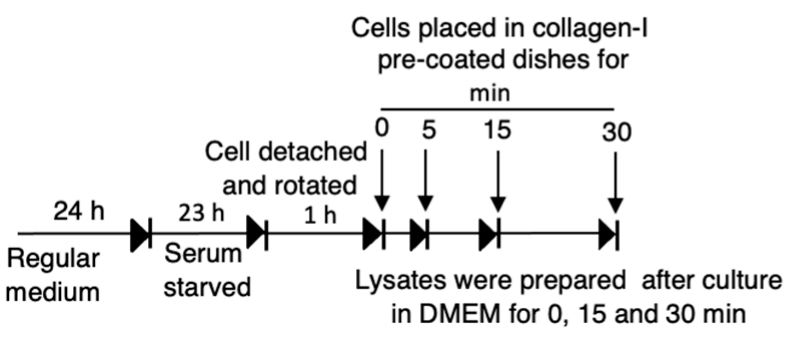

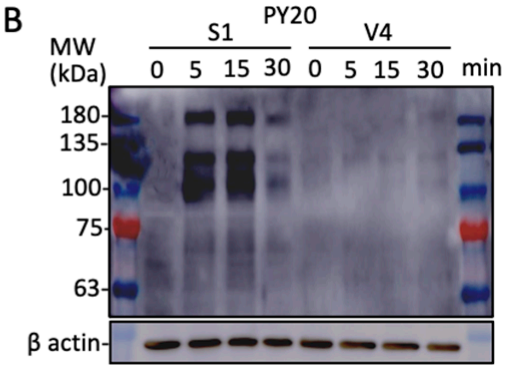

Figure 7. Adhesion signals activated during cell adhesion to collagen-coated plates. Tyrosinephosphorylated proteins were detected during cell adhesion. (A) Diagram for preparing cells to obtain lysates during cell adhesion. GD2+ (S1) and GD2- (V4) cells were detached using 0.02\% EDTA/PBS after culturing in serum-free DMEM at $37^{\circ} \mathrm{C}$ for $23 \mathrm{~h}$, and rotated at $37^{\circ} \mathrm{C}$ for $1 \mathrm{~h}$. Cell suspensions were placed in collagen I pre-coated plates in DMEM, and incubated as indicated at $37^{\circ} \mathrm{C}$. Then, cells were lysed and lysates were used for SDS-PAGE. (B) Immunoblotting was performed with anti-phosphotyrosine PY20 mAb. Anti- $\beta$ actin Ab was used as a loading control.

\subsection{Knockdown of Integrin B1 in GD2+ Cells Altered Their Phenotypes to Those of GD2- Cells}

Effects of 4 siRNAs to compare the knockdown efficiency of integrin $\beta 1(37,75,74$, and ITG1) were examined with Western immunoblotting (Figure 8A) and qRT-PCR (Figure 8B). Then, we selected ITG1 si-RNA and examined the effects of the knockdown of integrin $\beta 1$ on cell proliferation. As shown in Figure 8C, GD2+ cells show a clear reduction of cell growth after knockdown with ITG1 compared with GD2+ control cells, but GD2- cells do not show a significant difference from the levels of GD2- control cells. As for cell adhesion activity, the treatment with siRNA results in a significant decrease in adhesion, as shown in GD2+ cells (Figure 8D). The reduction of integrin $\beta 1$ was also shown. Regarding the effects of the knockdown on the invasion activity, the increased invasion activity of GD2+ cells was strongly suppressed to the levels of GD2- cells (Figure 8F), and their images are shown in Figure 8E. 
A

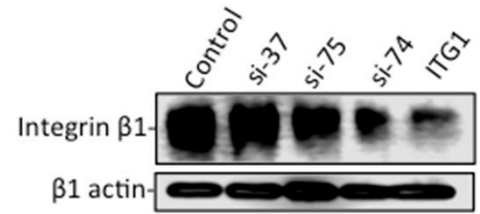

C
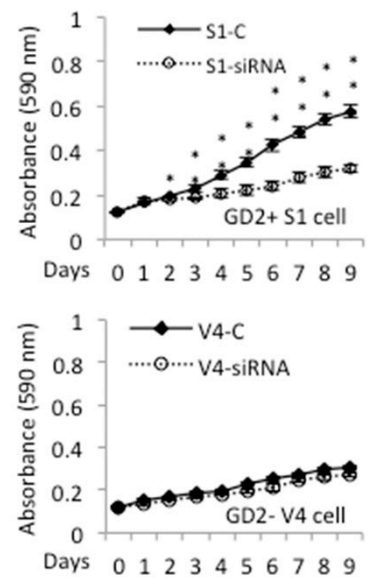

B
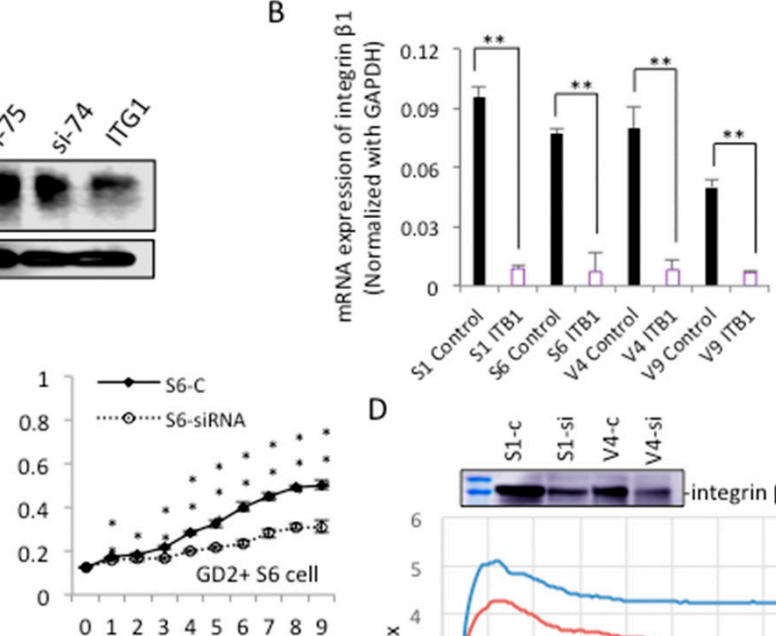

D

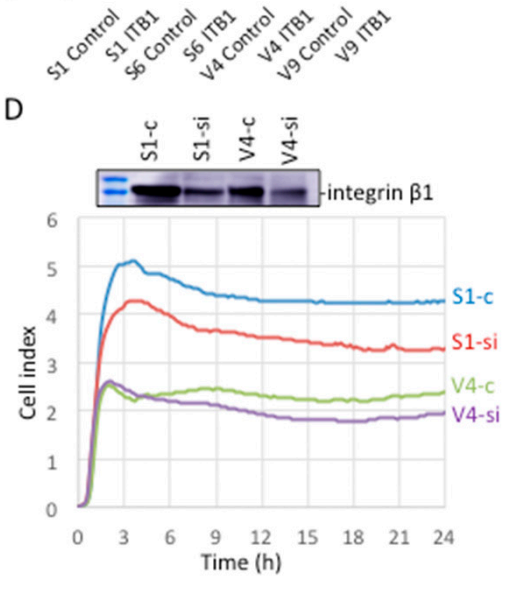

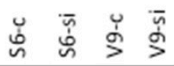

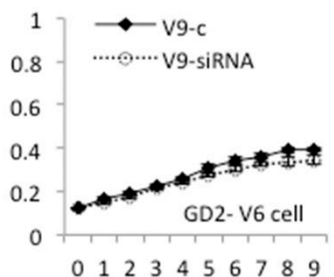

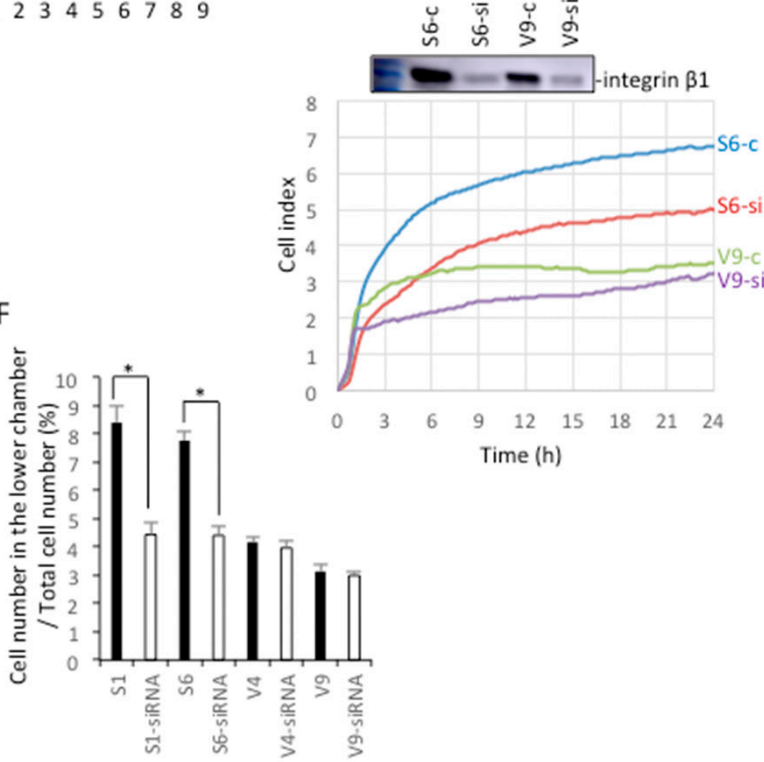

E

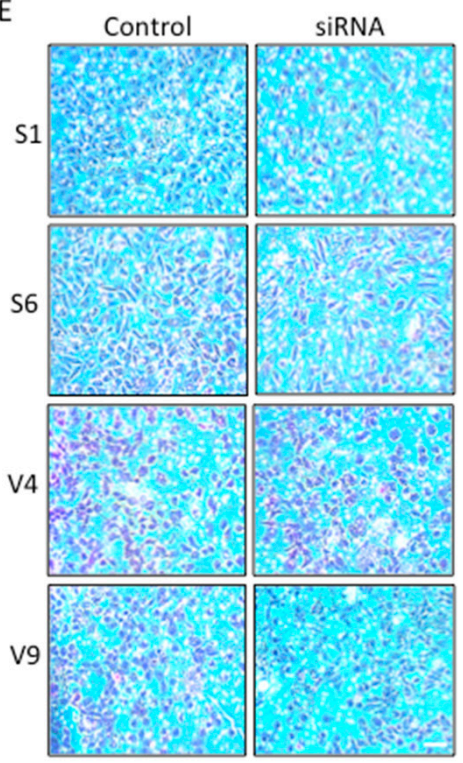

Figure 8. Knockdown of integrin $\beta 1$ and its effects on cell phenotypes. (A,B) Knockdown efficiency of integrin $\beta 1$ was examined with 4 types of $\operatorname{siRNA}(37,75,74$, and ITG1). Using cell lysates and RNAs from GD2+ and GD2- cells, Western immunoblotting (A) and qRT-PCR (B) were performed, respectively. Gene expression levels were analyzed using the Student's $t$-test. ${ }^{* *} p<0.01$. (C) Cell proliferation was analyzed by the MTT assay, using GD2+ and GD2- cells treated with anti-integrin $\beta 1$ si-RNA ITG1. Cells $\left(3 \times 10^{3}\right)$ were seeded in 96-well plates. MTT assay was performed, as described in Figure 2. The analysis was performed in triplicates (and the mean \pm SD are presented) and analyzed by two-way ANOVA with the Tukey post-hoc test. ${ }^{*} p<0.05,{ }^{* *} p<0.01$. (D) Cell adhesion was analyzed by the RT-CES system. GD2+ and GD2- cells were transfected with integrin $\beta 1$ si-RNA, ITG1, and used for RT-CES, as described in Figure 2. (E,F) Invasion activity was analyzed using GD2+ and GD2- cells treated by integrin $\beta 1$ si-RNA ITG1 with cell culture inserts. (F) A summary of the invasion assay. The invasion assay was performed in triplicates (and the mean \pm SD are presented) were analyzed by Student's $t$-test. ${ }^{*} p<0.05$. Scale bar $=20 \mu \mathrm{m}$. 
Immunoblotting with anti-phosphotyrosine mAb PY20 was performed using lysates from cells transfected with anti-integrin $\beta 1$ si-RNA ITG1. After a $36 \mathrm{~h}$ culture in a regular medium, and the subsequent starvation in serum-free DMEM for $23 \mathrm{~h}$, cells were incubated in collagen I precoated plates for 0 30 min, and underwent immunoblotting with PY20. Surprisingly, the phosphorylated bands in GD2+ cell-derived samples largely disappeared, as shown in Figure 9. All these results suggest that the increased malignant properties and signals detected in GD2+ cells are dependent on the expression of integrins, based on their association and cooperation on the cell surface.

\subsection{Integrin B1 and GD2 Co-Localized in GEM/Rafts before and during the Adhesion to CL Type I} in GD2+ Cells

Cells were detached using $0.02 \%$ EDTA/PBS, and placed in collagen I pre-coated plates in DMEM. After incubation for $0 \sim 30 \mathrm{~min}$ at $37^{\circ} \mathrm{C}$, cell lysates were prepared and fractionated by Optiprep gradient ultracentrifugation at $42,000 \mathrm{rpm}$ and $4{ }^{\circ} \mathrm{C}$ for $5 \mathrm{~h}$. These fractions were used for immunoblotting with anti-integrin $\beta 1 \mathrm{mAb}$, anti-GD2 $\mathrm{mAb}$, antiflotillin, and anti-caveolin-1 antibodies, as shown in Figure 10A. Band intensities of integrin $\beta 1$ were plotted. As shown in Figure 10B, integrin $\beta 1$ was found in fractions (fr.) $2 \sim 4$ as well as in fr. $6 \sim 10$ in GD2+ cells. On the other hand, integrin $\beta 1$ can only be found in fr. $6 \sim 10$ in GD2 - cells at $0 \sim 5 \mathrm{~min}$, during adhesion. After $15 \mathrm{~min}$, integrin $\beta 1$ was broadly distributed in both the GD2+ and GD2- cells.

A

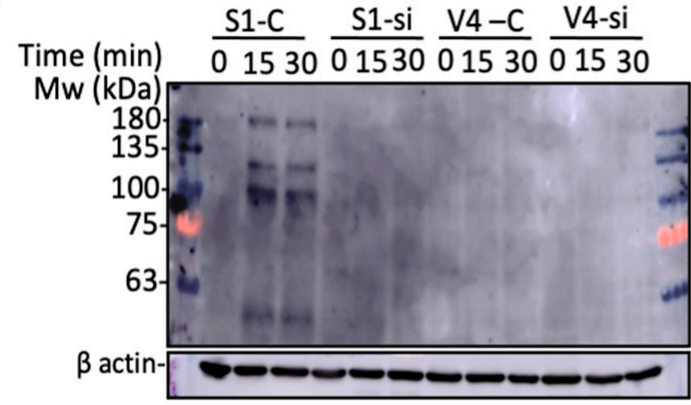

B

a

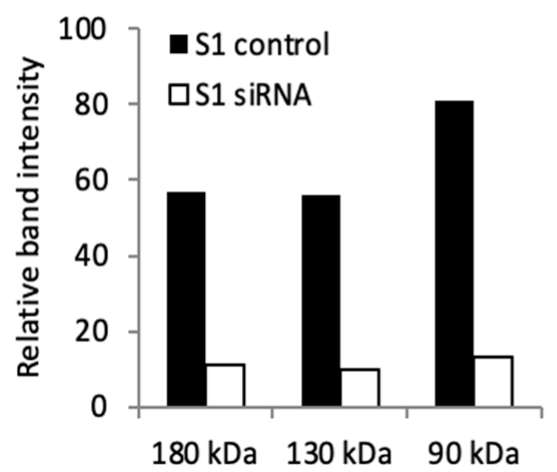

b

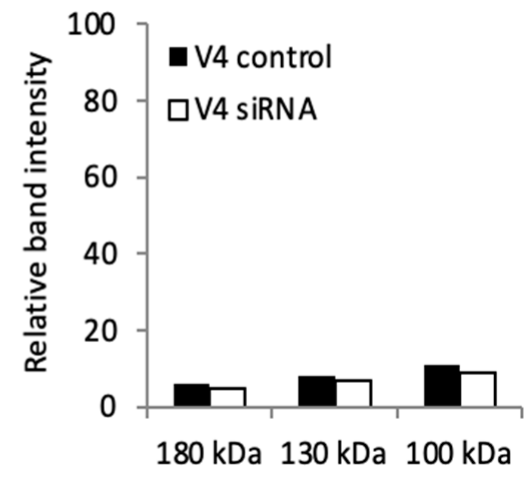

Figure 9. Multiple phospho-tyrosine bands were detected during the cell adhesion of GD2+ cells. (A) Immunoblotting with anti-phosphotyrosine mAb PY20. GD2+ S1 and GD2- V4 cells were transfected with anti-integrin $\beta 1$ si-RNA ITG1. After $36 \mathrm{~h}$ of culture in regular medium, the cells were prepared, as described in Figure 7. Then, the cells were lysed and used for immunoblotting. (B) Band intensities in A were scanned by Images $\mathrm{J}^{\mathrm{TM}}$ and plotted for S1 bands (a) and V4 bands (b). 


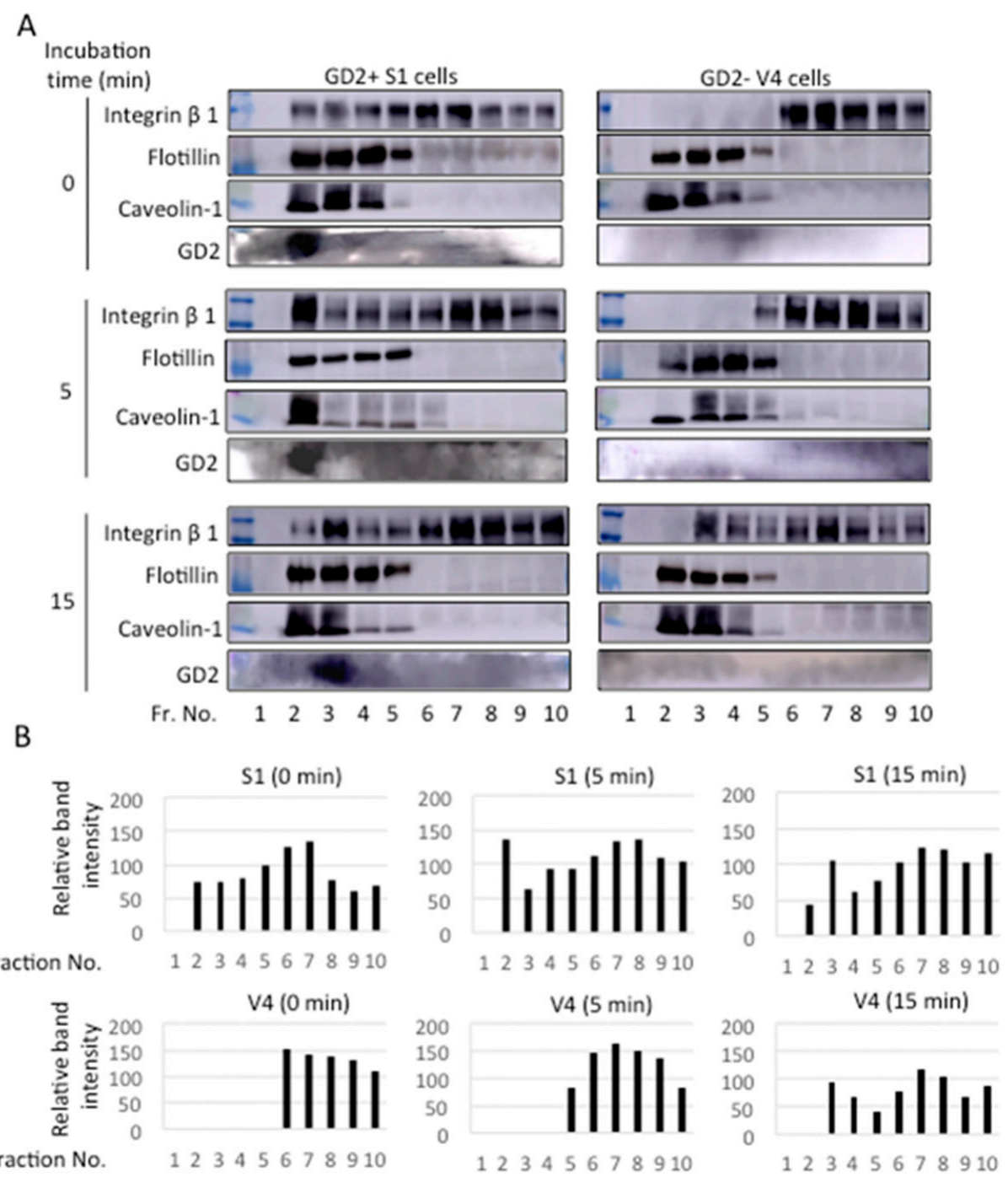

Figure 10. Intracellular distribution of integrin $\beta 1$ before and during adhesion to CL type I. (A) GD2+ (S1) and control GD2- (V4) cells were detached using $0.5 \mathrm{mM}$ EDTA/PBS. Cell suspension $\left(5 \times 10^{5}\right.$ cells) was placed in collagen I pre-coated plates in DMEM, and incubated for 0 30 min at $37^{\circ} \mathrm{C}$. Then, cell lysates were prepared using $1 \%$ Brij 020 in a TNE buffer and separated by Optiprep gradient ultracentrifugation at $42,000 \mathrm{rpm}$ and $4{ }^{\circ} \mathrm{C}$ for $5 \mathrm{~h}$, and fractionated $(500 \mu \mathrm{L})$. Each fraction $(13.5 \mu \mathrm{L})$ was used for immunoblotting with anti-integrin $\beta 1 \mathrm{mAb}$, anti-GD2 $\mathrm{mAb}$, anti-flotillin, or anti-caveolin-1 antibodies. Flotillin and caveolin-1 were used as GEM/raft markers. (B) Band intensities of integrin $\beta 1$ were measured by Image $\mathrm{J}^{\mathrm{TM}}$ software and the relative intensity of bands are presented.

\section{Discussion}

Gangliosides are expressed at high levels in the nervous tissues among normal tissues [1]. However, their characteristic expression in neuroectoderm-derived malignant cells, such as malignant melanomas, neuroblastomas, gliomas, and small cell lung cancers, [4] was reported, leading to their expected clinical application as cancer-associated glycolipids. They have also been reported to be expressed in osteosarcomas [23-25], breast cancers [26], and T-cell leukemias [27-30]. Attention to GD2 is especially increasing, i.e., as cancer-associated glycolipids in various cancers, and a marker to indicate higher malignant properties of cancers [22], and/or cancer stem cells [17] and triple-negative breast cancers [18]. GD2 has been used as a target of antibody therapy [31,32] towards neuroblastomas [33], gliomas [34], and breast cancers [26], and also of CAR-T therapy of various cancers $[19,20]$. Furthermore, the biological function of GD2 has been reported, i.e., in 
EMT [35,36], tumor invasion [37], and cancer metastasis [38], though it had been expected based on the clinical samples with different disease stages [16]. Thus, they have attracted interest from medical and biological science fields. In particular, GD2 is now expected to be a target to protect cancer metastasis, since metastasis is the most serious cause for cancer death. However, it is not well-understood how GD2 is involved in cancer metastasis.

EMARS/MS was developed by Kotani and Honke [11], and has been shown to be an efficient approach to investigate the mechanisms by which membrane molecules exert significant effects on the cell membrane [15]. Particularly for glycosphingolipids, the identification of physically associating molecules on the cell surface can be crucial to understand their roles in cell signal transduction [39], because of their modes of membrane anchoring. Glycosphingolipids are expressed on the outer layer of the lipid bilayer membrane lacking a cytoplasmic domain [40]. Therefore, they need to physically associate with membrane molecules containing cytoplasmic domains, in order to modulate signals introduced via the cell membrane. Then, the EMARS/MS approach should bring about enormous progress in the understanding of the mechanisms for signal regulation by glycosphingolipids. Thus, the functional analysis of cancer-associated glycolipids is now entering a new era [15].

The current biochemical isolation method of lipid rafts contains some unclear issues, i.e., the isolated raft fraction members do not necessarily co-exist on the same membrane microdomains. On the other hand, molecules defined by EMARS/MS with a particular target can directly be considered to be present closely enough to be expected to physically and functionally cooperate on the living cells.

In this study, we identified integrin $\beta 1$ as a representative membrane molecule in GD2+ melanoma cells. Previously, we reported that neogenin is a GD3-associated membrane molecule on melanoma cells [13], and elucidated that the intracellular domain of neogenin was cleaved by $\gamma$-secretase in GEM/rafts, and plays important roles as a GD3-drived effector [13]. It is very interesting that the EMARS-MS analysis revealed different membrane molecules associating with two gangliosides, GD3 and GD2, although these gangliosideexpressing transfectant cells were generated from the same melanoma cell, an SK-MEL-28 mutant, N1 cell line [16]. These results suggest that individual gangliosides form distinct molecular clusters on the cell membrane, and play individually characteristic roles in the processes of cancer generation, progress, and expansion.

Molecular clustering around GD2 in GEM/rafts should be further clarified, and the association of GD2/integrins with EGFR and FAK, for instance, is also an area to be urgently examined. This is because these molecular clusters, formed around cancerassociated gangliosides, can be promising targets of cancer treatment with higher specificity and stronger efficiency.

While close relationships between gangliosides and integrins have been reported [41], we also showed that ganglioside GD3 enhanced the cell adhesion of melanoma cells by forming a molecular complex with integrins [42], and the association of GD2 and integrins can be more intense when considering its role in cancer metastasis. It is surprising that the increased malignant properties based on GD2 expression were cancelled by the knockdown of integrin $\beta 1$, suggesting that GD2 is essentially involved in cell adhesion, depending on integrin $\beta 1$. In fact, anti-GD2 mAb very strongly suppressed cell adhesion, just as observed by the knockdown of integrin $\beta 1$, as shown in Figure 3.

Whether GD2 is always positively involved in cell adhesion is unclear. At this moment, it is considered to be dependent on the types of cancers. In RT-CES, GD2+ melanoma cells showed a stronger cell adhesion in this melanoma study. On the other hand, GD2 expression resulted in the apparent reduction of cell adhesion in osteosarcoma cells, as previously reported [23]. This discrepancy in the effects of GD2 expression on the cell adhesion depends on the type of cancer cells, i.e., melanomas and osteosarcomas in which different signaling molecules are expressed [43]. As for cell invasion activity, GD2+ cells showed increased invasion activity, compared with GD2- cells in this study. In a previous report, we observed a reduced invasion activity in GD2+ melanomas, as measured by the Boyden chamber method [22]. The difference in the invasion activity of GD2+ cells should 
come from different experimental settings, i.e., the presence or absence of FCS in the lower chamber that acts as a chemoattractant. Thus, GD2+ cells can show rather reduced invasion under the no FCS condition. These results show that we must carefully select experimental conditions for cell phenotypic analyses.

Consequently, we need to elucidate the effects of cancer-associated gangliosides to distinguish the universal effects and specific effects in some particular cancers on an individual basis. Then, we will be able to apply anti-ganglioside probes to treat individual cancer types.

\section{Materials and Methods}

\subsection{Cell Culture}

Ganglioside GD2-expressing S1 and S6 clones were established from a human melanoma cell SK-MEL-28 subline, N1 [21], by transfecting with cDNAs of ST8SIA1 [44] and B4GALNT1 [45]. The N1 cell was provided by K.O. Lloyd (Memorial Sloan Kettering Cancer Center, New York, NY, USA), as reported in [21]. V4 and V9 clones were established as vector controls [22] (Figure 1A). S1 and S6 clones were grown in Dulbecco's minimal essential medium (DMEM) containing 7.5\% fetal bovine serum (FBS) and G418 (600 $\mu \mathrm{g} / \mathrm{mL})$, and vector control V4 and V9 clones were grown in DMEM containing 7.5\% FBS and G418 $(400 \mu \mathrm{g} / \mathrm{mL})$ at $37{ }^{\circ} \mathrm{C}$ in a humidified atmosphere containing $5 \% \mathrm{CO}_{2}$.

\subsection{Mice}

Eight-week-old immunocompromised mice (Chubu Science Co. Ltd., Nagoya, Japan) were used to generate ascites of anti-GD2 mAb 220-51. Animal experimental protocols were approved by the committee on Laboratory Animals in Chubu University (No. 3010006), consistent with the guidelines of the Japanese government, as well as the National Institutes of Health Guide for the Care and Use of Laboratory Animals (1966). Mice were maintained under specific pathogen-free conditions.

\subsection{Antibodies and Reagents}

Anti-GD2 mAb, 3F8, was provided by N. K. Cheung (Sloan Kettering Cancer Center, New York, NY, USA) [46] and 220-51 was generated in our laboratory [47]. Anti-GD3 mAb and anti-GM2 mAbs were provided by L.J. Old at the Memorial Sloan Kettering Cancer Center (New York). The other antibodies and reagents were obtained from the following commercial sources: fluorescein isothiocyanate (FITC)-conjugated goat anti-mouse IgG $(\mathrm{H}+\mathrm{L})$ from Cappel (Durham, NC, USA); horseradish peroxidase (HRP)-conjugated anti-mouse IgG antibody; HRP-conjugated anti-rabbit IgG antibody; HRP-conjugated anti-goat IgG antibody; rabbit anti-FITC antibody; and goat anti-FITC antibody from Cell Signaling Technology (Danvers, MA, USA). Mouse anti-integrin $\beta 1 \mathrm{mAb}$, anti-Flotillin-1 $\mathrm{mAb}$, anti-Caveolin-1 Ab, and anti-integrin $\beta 1(\mathrm{CD} 29) \mathrm{mAb} 4 \mathrm{~B} 7 \mathrm{R}$ were from Santa Cruz Biotechnology (Santa Cruz, CA, USA). Rabbit anti-integrin $\beta 1$ polyclonal Ab was from Bioss, Woburn, MA, USA. Mouse anti-phosphotyrosine antibody PY20 was from Santa Cruz Biotechnology (Santa Cruz, CA, USA). Alexa 488-conjugated anti-rabbit IgG antibody and Alexa 568-conjugated anti-mouse IgG antibody were from Invitrogen (Carlsbad, CA, USA). Monoclonal anti- $\beta$ actin antibody was from Sigma-Aldrich (St. Louis, MO, USA). Protein A Sepharose $^{\mathrm{TM}} 4$ Flast Flow beads were from GE Healthcare. Giemsa was from Wako (Osaka, Japan), Matrigel ${ }^{\mathrm{TM}}$ was from BD Bioscience and collagen-1 was from Sigma-Aldrich (St. Louis, MO, USA). FITC-conjugated tyramine (FT), BSA, dithiothreitol, iodoacetamide, ammonium bicarbonate, and Lys-C were from Wako (Osaka, Japan). Cell lysis buffer was from Cell Signaling Technology (Danvers, MA, USA), and Protease Inhibitor MixtureTM was from Calbiochem (San Diego, CA, USA). The ImmunoStar ${ }^{\mathrm{TM}}$ LD detection kit was from Wako (Osaka, Japan), and OptiPrep ${ }^{\mathrm{TM}}$ and 1\% 020 Brij were purchased from Sigma-Aldrich (St. Louis, MO, USA). 


\subsection{Flow Cytometry}

The expression levels of ganglioside GD2 on the cell membrane were analyzed by Accuri ${ }^{\mathrm{TM}}$ C6 Flow Cytometer (Accuri Cytometers Inc., Ann Arbor, MI, USA), as previously described [48,49]. Briefly, trypsinized cells $\left(5 \times 10^{5}\right)$ were washed twice with cold PBS, and incubated with diluted antibodies in PBS for $60 \mathrm{~min}$ on ice. After washing twice with PBS, cells were stained with FITC-conjugated goat anti-mouse IgG (H + L) (Cappel, Durham, NC, USA) as a secondary antibody for $45 \mathrm{~min}$ on ice. Then, cells were washed twice with PBS, and the relative expression levels were analyzed by flow cytometry. Control samples were prepared using non-relevant $m A$ bs with the same subclasses as the individual primary antibodies. The CFlow plus ${ }^{\mathrm{TM}}$ program was used for the quantification of positive cells.

\subsection{Immunofluorescence Assay}

Cells (500 cells/well/10 $\mu \mathrm{L}$ ) were seeded in each well of 60-well Terasaki plates, and incubated in regular medium overnight. The supernatants were removed gently, and the diluted antibodies were applied to individual wells and incubated for $1 \mathrm{~h}$ at room temperature (RT). After being washed twice with PBS containing 5\% FBS, FITC-conjugated anti-mouse IgG $(\mathrm{H}+\mathrm{L})$ (Cappel, Durham, NC, USA) was applied, and the plates were incubated for $1 \mathrm{~h}$ at RT. Then, the cells were washed twice with PBS containing 5\% FBS. Antigen was detected by fluorescence microscopy (IX2-ILL100, OLYMPUS, Tokyo, Japan).

\subsection{MTT Assay}

Cells $\left(3 \times 10^{3}\right)$ were seeded in each well of 96-well plates with $100 \mu \mathrm{L}$ of DMEM supplemented with 7.5\% FBS. During culture, $10 \mu \mathrm{L}$ MTT (3-(4,5-dimethylthiazol-2-yl)-2,5diphenyltetrazolium bromide) ( $5 \mathrm{mg} / \mathrm{mL}$ PBS) solution was added to each well on days $0,1,2,3,4,5,6,7,8$, and 9 , and incubated for $4 \mathrm{~h}$ at $37^{\circ} \mathrm{C}$. The reaction was stopped by adding $110 \mu \mathrm{L}$ of 1 -propanol containing $0.4 \% \mathrm{HCl}$ and $0.1 \% \mathrm{NP}-40$. Then, absorbance was measured at $590 \mathrm{~nm}$ using an automatic microplate reader (Thermo Fisher Scientific, Type: 357, Shanghai, China).

\subsection{Invasion Assay}

An invasion assay was performed using cell culture inserts (Transparent $\mathrm{PET}^{\mathrm{TM}}$ membrane, 24-well format, 8.0- $\mu$ m pore size, Life Sciences, Durham, NC, USA), as described [14]. Matrigel $^{\mathrm{TM}}$ (BD Bioscience) $20 \mu \mathrm{L}$ in cold PBS $(200 \mu \mathrm{g} / \mathrm{mL})$ was added to the upper chamber of cell culture inserts, and incubated for $2 \mathrm{~h}$ at room temperature to promote polymerization. After removing PBS, the upper chamber was filled with $200 \mu \mathrm{L}$ serum-free DMEM and incubated for $1 \mathrm{~h}$, and the lower chamber was filled with DMEM containing $10 \%$ FBS. After removing the medium from the upper chamber, cells $\left(3 \times 10^{4}\right)$ in $200 \mu \mathrm{L}$ serum-free DMEM were added, and incubated for $24 \mathrm{~h}$ at $37^{\circ} \mathrm{C}$ in a humidified atmosphere containing $5 \% \mathrm{CO}_{2}$. After incubation, invaded cells on the surface of the lower chamber were stained with Giemsa (Wako, Osaka, Japan), and the number of cells was counted under microscope (IX73P1F ${ }^{\mathrm{TM}}$, Olympus, Tokyo, Japan).

\subsection{Cell Adhesion Assay}

The cell adhesion experiment was performed using the real-time cell electronic sensing system (RT-CES ${ }^{\mathrm{TM}}$ ) (Wako Pure Chemical, Osaka, Japan), as previously described [22]. At the bottom of the microplates (E-Plate (16X) (ACEA Biosciences Inc., San Diego, CA, USA), microelectronic cell sensor arrays are integrated. The sensor provides information on the increased electrical resistance (cell index), indicating the increase in cell adhesion. E-plates were coated with Collagen-1 (CL-1) $(5 \mu \mathrm{g} / \mathrm{m}$ in PBS, $100 \mu \mathrm{L} /$ well) at RT for $1 \mathrm{~h}$, and blocked by $1 \%$ BSA $/ 10 \%$ FBS in D-MEM $(100 \mu \mathrm{L} /$ well $)$ at RT for $1 \mathrm{~h}$. After blocking the wells, the cells $\left(1 \times 10^{4}\right)$ were seeded in each well of the plates containing the culture medium. Changes of cell adhesion were monitored continuously, and expressed as the cell index. 


\subsection{Cell Lysate Preparation}

Cells were washed three times with PBS, and lysed using a cell lysis buffer $(20 \mathrm{mM}$ Tris- $\mathrm{HCl}, 150 \mathrm{mM} \mathrm{NaCl}, 1 \mathrm{mM}$ EGTA, 1 mM Na2EDTA, 1\% Triton X-100, $2.5 \mathrm{mM}$ sodium pyrophosphate, $1 \mathrm{mM} \beta$-glycerophosphate, $1 \mathrm{mM} \mathrm{Na3VO} 4$, and $1 \mu \mathrm{g} / \mathrm{mL}$ leupeptin) (Cell Signaling Technology, Danvers, MA, USA), supplemented with $1 \mathrm{mM}$ phenylmethylsulfonyl fluoride (PMSF) and Protease Inhibitor MixtureTM (Calbiochem, San Diego, CA, USA). Cell lysates were centrifuged at 12,500 rpm (Kubota 3740TM, Tokyo, Japan) for $10 \mathrm{~min}$ at $4{ }^{\circ} \mathrm{C}$ to remove insoluble cell debris, and proteins in supernatants were measured using the DC protein assay kit (Bio-Rad, Hercules, CA, USA).

\subsection{EMARS and MS Analysis}

The EMARS reaction and MS of EMARS products were carried out, as described [11,50,51]. Briefly, the cells $\left(5.0 \times 10^{5}\right)$ were treated with purified mouse anti-GD2 mAb 220-51 in 6-cm dishes after washing with PBS, and incubated for $45 \mathrm{~min}$ at RT. Then, HRP-conjugated anti-mouse IgG in PBS was added and incubated for $30 \mathrm{~min}$ at RT. After washing twice with PBS, (FITC)-conjugated tyramine (FT) solution diluted in PBS was added (0.1 mM FT/PBS) to the dishes and incubated in dark place for $15 \mathrm{~min}$ at RT. After the addition of $\mathrm{H}_{2} \mathrm{O}_{2}$ to the dishes and 5 min incubation, cells were washed twice with PBS and scraped by adding $100 \mathrm{mM}$ Tris- $\mathrm{HCl}$ (pH 7.4) and $1 \mathrm{mM}$ PMSF. After centrifugation, pellets were dissolved by adding an RIPA buffer (50 mM Tris $\mathrm{HCl}$, pH 7.4, $150 \mathrm{mM} \mathrm{NaCl}, 1 \%$ NP40. 0.5\% sodium deoxycholate, and $0.1 \%$ SDS), and $1 \mathrm{mM}$ phenylmethylsulfonyl fluoride (PMSF) was then added. The FITC-labeled molecules were immunoprecipitated with the rabbit anti-FITC antibody, and the efficiency of the EMARS reaction was confirmed by SDS-PAGE and the subsequent immunoblotting using goat anti-FITC antibody.

Then, immunoprecipitates were prepared for MS analysis by dissolving with an MS sample buffer (12 mmol/L sodium lauroylsarcosine, $12 \mathrm{mmol} / \mathrm{L}$ sodium deoxycholate, and $100 \mathrm{mmol} / \mathrm{L}$ Tris- $\mathrm{HCl}(\mathrm{pH} \mathrm{8.0)})$, then boiling at $95^{\circ} \mathrm{C}$, and centrifugation at 20,000 $\mathrm{g}$ for $15 \mathrm{~min}$. Dithiothreitol and iodoacetamide were used for reduction and alkylation, respectively. Then, the samples were diluted with $50 \mathrm{mmol} / \mathrm{L}$ ammonium bicarbonate and digested by Lys-C (Wako, Osaka, Japan) for $3 \mathrm{~h}$, followed by digestion with trypsin for $8 \mathrm{~h}$ at $37^{\circ} \mathrm{C}$. The samples were desalted and concentrated with C18 Stage-Tips ${ }^{\mathrm{TM}}$ (Thermo Fisher Scientific, Waltham, MA, USA). Mass spectrometry was performed using an LTQOrbitrap Velos mass spectrometer (Thermo Fisher Scientific) system coupled with nano-LC (EASY-nLC II, Thermo Scientific). Detailed procedures were described in the Supportive information. Combined MS spectra (Tandem) were processed using Proteome Discoverer software (version 1.3, Thermo Fisher Scientific) workflow and searched using the program Mascot 2.4 (Matrix Science, Boston, MA, USA) and X! Tandem (The Global Proteome Machine; http:/ / www.thegpm.org/tandem/), against the Swiss-Prot protein database. This was performed on 12 November 2018.

As for the identification of tyrosine-phosphorylated bands detected by the PY20 antibody in immunoblotting, an MS analysis of tyrosine-phosphorylated proteins was performed by using gel extracts, as previously described [49].

\subsection{Western Blotting}

After preparation of the cell lysates, the proteins in cell lysates were separated in SDSPAGE using 10\% gels. The separated proteins in gels were transferred onto an Immobilon-P membrane (EMD Millipore, Burlington, MA, USA), and blots were blocked for $1 \mathrm{~h}$ with 3\% skimmed milk or bovine serum albumin (BSA) in PBS, including $0.05 \%$ Tween-20. Then, the membrane was incubated with primary antibodies, followed by HRP-labeled secondary antibodies. Bands of proteins were visualized using ImmunoStar ${ }^{\mathrm{TM}}$ LD detection kits (Wako Osaka, Japan), and analyzed by Imager LI-COR ${ }^{\mathrm{TM}}$ (Model: 3600, LI-COR, Inc., Lincoln, NE, USA). 


\subsection{Immunoprecipitation}

Cells were washed three times with PBS and lysed to prepare cell lysates, as mentioned above. After removing insoluble cell debris through centrifugation, The supernatants of cell lysates were used for the immunoprecipitation of integrin $\beta 1$ with rabbit anti-integrin $\beta 1$ polyclonal Ab (Bioss, MA, USA), or the immunoprecipitation of phosphorylated signaling molecules with the mouse anti-phosphotyrosine antibody PY20 (Santa Cruz Biotechnology, Santa Cruz, CA, USA) at $4{ }^{\circ} \mathrm{C}$ overnight with rotation. Protein G Sepharose 4 fast flow ${ }^{\mathrm{TM}}$ beads (GE Healthcare, Uppsala, Sweden) were used to capture the immune complex. After washing the beads with immune complex, a sodium dodecyl sulfate (SDS) sample buffer (2X) was added and boiled at $95^{\circ} \mathrm{C}$ for $3 \mathrm{~min}$. Then, an immunoprecipitated complex was applied for SDS-polyacrylamide gel electrophoresis (SDS-PAGE).

\subsection{Real-Time RT-PCR}

Total RNA extraction was performed with a TRIzol ${ }^{\mathrm{TM}}$ reagent (Invirogen), and a cDNA template was synthesized from the total RNA using the MMLV reverse transcriptase kit (Invitrogen), as described previously [49]. Briefly, $2 \mu \mathrm{g}$ total RNA was used for the synthesis of cDNA with MMLV reverse transcriptase. Synthesized cDNA (8 ng) was amplified in a $20 \mu \mathrm{L}$ reaction volume containing a $10 \mu \mathrm{L}$ SsoAdvanced ${ }^{\mathrm{TM}}$ Universal SYBR green Supermix ${ }^{\mathrm{TM}}$ qPCR kit (Bio-Rad Laboratories, Hercules, CA, USA) and $1 \mu \mathrm{L}$ of each $5 \mu \mathrm{M}$ primer. The primers were designed as forward (5'-GCTGGTGTGGTTGCTGGAATTG$\left.3^{\prime}\right)$ and reverse (5'- GACCACAGTTGTTA-CGGCACTC- $\left.3^{\prime}\right)$, for integrin $\beta 1$. The PCR program was carried out with initial denaturation at $95^{\circ} \mathrm{C}$ for $30 \mathrm{~s}$, followed by 40 cycles of amplification $\left(95^{\circ} \mathrm{C}\right.$ for $5 \mathrm{~s}, 58^{\circ} \mathrm{C}$ for $30 \mathrm{~s}$, and $65{ }^{\circ} \mathrm{C}$ for $\left.5 \mathrm{~s}\right)$.

\subsection{Immunocytochemistry}

Immunocytochemistry was performed, as previously mentioned [52]. GD2+ (S1 and S6) and GD2- (V4 and V9) cells were plated in glass-bottomed dishes (Iwaki, Tokyo, Japan) and incubated in DMEM containing 7.5\% FBS at $37^{\circ} \mathrm{C}$ for $24 \mathrm{~h}$. After washing with cold PBS, the cells were fixed with $4 \%$ paraformaldehyde in PBS for $10 \mathrm{~min}$ at room temperature (RT). Cells were blocked with 5\% BSA in PBS for $1 \mathrm{~h}$ at RT. Immunostaining was performed with anti-GD2 mAb (m-220-51) and anti-integrin $\beta 1$ polyclonal Ab (Bioss, Massachusetts, USA) in $2 \%$ BSA/PBS as primary antibodies for $1 \mathrm{~h}$ at RT. Samples were washed with $1 \%$ BSA/PBS, and incubated with an Alexa fluor 568 conjugated goat anti-mouse-IgG (Invitrogen) and an Alexa fluor 488 conjugated donkey anti-rabbit IgG (Invitrogen) in $2 \%$ BSA/PBS for $1 \mathrm{~h}$ at RT. After being washed, the cell nucleus was stained with DAPI in $2 \%$ BSA/PBS for $15 \mathrm{~min}$, and mounted with Pro-Long anti-fade reagent. Then, the cells were analyzed by a confocal microscope (Fluoview FV10i; Olympus, Tokyo, Japan).

\subsection{Preparation of GEM/Rafts Fractions}

Cells $\left(2.5 \times 10^{7}\right)$ were washed with cold PBS and lysed with TNE buffer $(25 \mathrm{mM}$ Tris-HCL (pH 7.4), $150 \mathrm{mM} \mathrm{NaCl}$, and 5 mM EDTA) containing BRIJ ${ }^{\mathrm{TM}} 020$ (Sigma-Aldrich, St. Louis, MO, USA) and $1 \mathrm{mM}$ PMSF. Lysates were homogenized 10 times with a Digital Homogenizer $^{\mathrm{TM}}$ (AS ONE, Osaka, Japan) or suspended with a 24-gauge needle. Homogenates were incubated on ice for $30 \mathrm{~min}$, and centrifuged at $4{ }^{\circ} \mathrm{C}, 1000 \mathrm{rpm}$ for $5 \mathrm{~min}$ to remove insoluble materials. The lysates $(350 \mu \mathrm{L})$ were mixed with $700 \mu \mathrm{L}$ OptiPrep ${ }^{\mathrm{TM}}$ (Sigma-Aldrich, St. Louis, MO, USA) to a final concentration of $40 \%$ OptiPrep [53]. The mixture was carefully overlaid with $2 \mathrm{~mL}$ of 30\% OptiPrep in TNE, followed by $950 \mu \mathrm{L}$ of 5\% OptiPrep. Gradient formation was performed by centrifugation for $5 \mathrm{~h}$ at $4{ }^{\circ} \mathrm{C}$ and 42,000 rpm using a Beckman MLS50 rotor (Kent, MI, USA). Each fraction was collected as $400 \mu \mathrm{L}$ from the top of the gradient and applied for Western immunoblotting.

\subsection{Proximity Ligation Assay (PLA)}

The proximity ligation assay (PLA) was performed using a Duolink in situ PLA kit (Sigma-Aldrich), according to the manufacturer's procedure. In brief, cells $\left(2 \times 10^{5}\right)$ were 
plated in a glass base dish (Iwaki/Asahi Glass Co., Funahashi, Japan) pre-coated with $0.01 \%$ poly-L-lysine (Sigma-Aldrich), and incubated for $24 \mathrm{~h}$ in DMEM supplemented with $7.5 \%$ FBS. After washing with cold PBS, the cells were fixed with $4 \%$ paraformaldehyde in PBS for 10 min at RT. Then, the cells were blocked with $10 \%$ donkey serum in PBS for $1 \mathrm{~h}$, and incubated with mouse anti-GD2 $\mathrm{mAb}$ (220-51) and rabbit anti-integrin $\beta 1 \mathrm{Ab}$ in $0.5 \%$ donkey serum albumin in PBS for $1 \mathrm{~h}$ at RT. The cells were washed twice with $0.05 \%$ Tween-20, and incubated with the Duolink in situ PLA probes anti-mouse PLUS and anti-rabbit MINUS for $1 \mathrm{~h}$ at $37^{\circ} \mathrm{C}$. After washing twice with buffer A (0.01 M Tris, $\mathrm{pH} 7.4$, $0.15 \mathrm{M} \mathrm{NaCl}$, and $0.05 \%$ Tween 20), a ligation solution was added and incubated for $30 \mathrm{~min}$ at $37^{\circ} \mathrm{C}$. Amplification was carried out using amplification reagent-polymerase solution for over $100 \mathrm{~min}$ at $37^{\circ} \mathrm{C}$. The samples were dried for approximately $10 \mathrm{~min}$ at room temperature in the dark, and mounted with a minimal volume of ProLong Gold antifade reagent with DAPI. The cells were analyzed under a confocal microscope (Fluoview FV10; Olympus, Tokyo, Japan).

\subsection{Statistical Analysis}

Data are presented as the means $\pm \mathrm{SD}$. The data were analyzed by two-way ANOVA with the a Tukey post-hoc test or an unpaired Student's two-tailed $t$-test, to compare mean values, as indicated in the individual figure legends. The $p$-values of $<0.05$ were considered significant. Those statistical significances were analyzed using R software (version 3.6.3) (https:/ / www.R-project.org). The analysis was performed on 1 September 2020.

Supplementary Materials: The following are available online at https://www.mdpi.com/article/ 10.3390/ijms23010423/s1.

Author Contributions: F.Y., R.H.B., Y.O. (Yuhsuke Ohmi), Y.O. (Yuki Ohkawa), T.O., K.F. (Keiko Furukawa), and K.F. (Koichi Furukawa) designed the study, and F.Y., R.H.B., Y.O. (Yuki Ohkawa), P.Z., K.H. (Kazunori Hamamura), K.K., O.T., M.K., T.O., S.Y., and K.F. (Keiko Furukawa) performed the study. N.K., N.-K.V.C., and K.H. (Koichi Honke) contributed the new analytical tools, and Y.O. (Yuhsuke Ohmi), N.K., T.O., K.F. (Keiko Furukawa), and K.F. (Koichi Furukawa) analyzed the data. F.Y. and K.F. (Koichi Furukawa) wrote the paper. All authors have read and agreed to the published version of the manuscript.

Funding: This study was supported by the Grants-in-Aids from the Ministry of Education, Culture, Sports and Technology of Japan (MEXT) (15H04696, 17K19616, 18H02628, 19K22518, 19K07393, 21K06828, 21H02699), and by JST-CREST (Grant Number: JPMJCR17H2).

Institutional Review Board Statement: Not applied.

Informed Consent Statement: Not applied.

Data Availability Statement: Not applied.

Acknowledgments: We thank S. Hosoya at the Inter-University Network for Common Utilization of Research Equipments, in Japan, for the MS analysis. We also thank N. Hashimoto at Tokushima University for valuable discussion, and Y. Kitaura, T. Ito, and Y. Imao for the excellent technical assistance.

Conflicts of Interest: Both Memorial Sloan Kettering Cancer Center (MSK) and NKC have financial interest in Y-mAbs, Abpro-Labs and Eureka Therapeutics. NKC reports receiving commercial research grants from Y-mabs Therapeutics. NKC was named as inventor on multiple patents filed by MSK, including those licensed to Y-mabs Therapeutics, Biotec Pharmacon, and Abpro-labs. NKC is a SAB member for Eureka Therapeutics. 


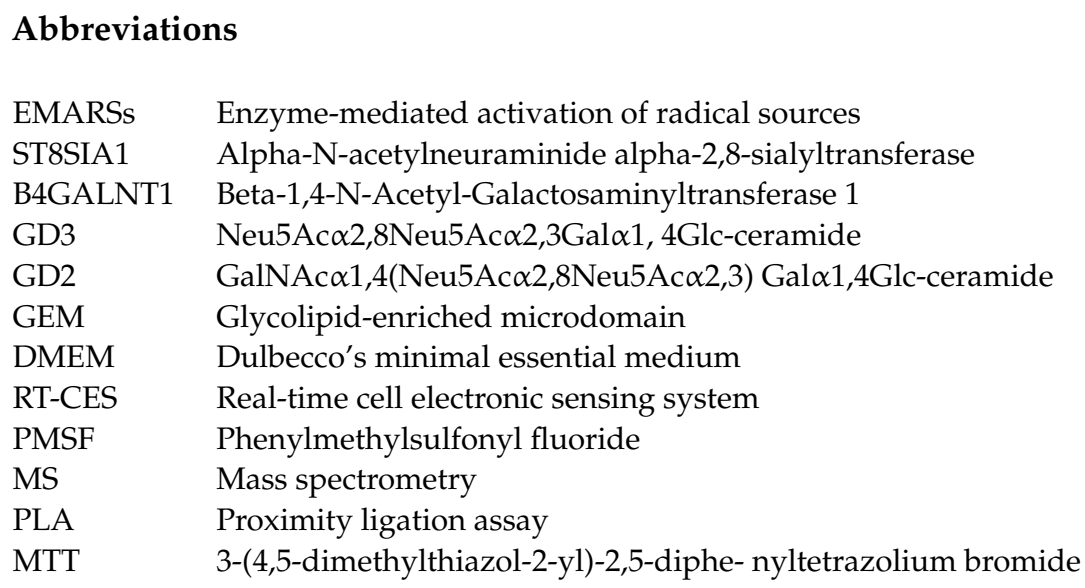

\section{References}

1. Wiegandt, H. Gangliosides. In Glycolipids; Wiegandt, H., Ed.; Elsevier: New York, NY, USA, 1985; pp. $199-259$.

2. Nagai, Y.; Tsuji, S. Significance of ganglioside-mediated glycosignal transduction in neuronal differentiation and development. Prog. Brain Res. 1994, 101, 119-126.

3. Hakomori, S. Glycosynapses: Microdomains controlling carbohydrate-dependent cell adhesion and signaling. Anais da Academia Brasileira de Ciências 2004, 76, 553-572. [CrossRef]

4. Lloyd, K.O.; Old, L.J. Human monoclonal antibodies to gly- colipids and other carbohydrate antigens: Dissection of the humoral im- mune response in cancer patients. Cancer Res. 1989, 49, 3445-3451. [PubMed]

5. Houghton, A.N.; Mintzer, D.; Cordon-Cardo, C.; Welt, S.; Fliegel, B.; Vadhan, S.; Carswell, E.; Melamed, M.R.; Oettgen, H.F.; Old L.J. Mouse monoclonal IgG3 antibody detecting GD3 ganglioside: A phase I trial in patients with malignant melanoma. Proc. Natl. Acad. Sci. USA 1985, 82, 1242-1246. [CrossRef] [PubMed]

6. Irie, R.F.; Morton, D.L. Regression of cutaneous metastatic melanoma by intralesional injection with human monoclonal antibody to ganglioside GD2. Proc. Natl. Acad. Sci. USA 1986, 83, 8694-8698. [CrossRef] [PubMed]

7. Cheresh, D.A.; Honsik, C.J.; Staffileno, L.K.; Jung, G.; Reisfeld, R.A. Disialoganglioside GD3 on human melanoma serves as a relevant target antigen for monoclonal antibody-mediated tumor cytolysis. Proc. Natl. Acad. Sci. USA 1985, 82, 5155-5159. [CrossRef] [PubMed]

8. $\quad$ Furukawa, K.; Ohmi, Y.; Yesmin, F.; Tajima, O.; Kondo, Y.; Zhang, P.; Hashimoto, N.; Ohkawa, Y.; Bhuiyan, R.H.; Furukawa, K. Novel Molecular Mechanisms of Gangliosides in the Nervous System Elucidated by Genetic Engineering. Int. J. Mol. Sci. 2020, 21, 1906. [CrossRef]

9. Furukawa, K.; Ohmi, Y.; Ji, S.; Zhang, P.; Bhuiyan, R.H.; Ohkawa, Y.; Tajima, O.; Hashimoto, N.; Furukawa. K. Glycolipids: Essential regulator of neuro-inflammation, metabolism and gliomagenesis. Biochim. Biophys. Acta (BBA)-Gen. Subj. 2017, 1861, 2479-2484. [CrossRef]

10. Hakomori, S.I. Structure and function of glycosphingolipids and sphingolipids: Recollections and future trends. Biochim. Biophys. Acta. 2008, 1780, 325-346. [CrossRef]

11. Kotani, N.; Gu, J.; Isaji, T.; Udaka, K.; Taniguchi, N.; Honke, K. Biochemical visualization of cell surface molecular clustering in living cells. Proc. Natl. Acad. Sci. USA 2008, 105, 7405-7409. [CrossRef]

12. Honke, K.; Kotani, N. The enzyme-mediated activation of radical source reaction: A new approach to identify partners of a given molecule in membrane microdomains. J. Neurochem. 2011, 116, 690-695. [CrossRef] [PubMed]

13. Kaneko, K.; Ohkawa, Y.; Hashimoto, N.; Ohmi, Y.; Kotani, N.; Honke, K.; Ogawa, M.; Okajima, T.; Furukawa, K.; Furukawa, K. Neogenin defined as a GD3-associated molecule by enzyme-mediated activation of radical sources confers malignant properties via intra-cytoplasmic domain in melanoma cells. J. Biol. Chem. 2016, 291, 16630-16643. [CrossRef] [PubMed]

14. Ohkawa, Y.; Momota, H.; Kato, A. Ganglioside GD3 enhances invasiveness of gliomas by forming a complex with platelet-derived growth factor receptor a and Yes kinase. J. Biol. Chem. 2015, 290, 16043-16058. [CrossRef] [PubMed]

15. Furukawa, K.; Ohmi, Y.; Ohkawa, Y.; Bhuiyan, R.H.; Zhang, P.; Tajima, O.; Hamamura, K.; Furukawa, K. New era of research on cancer-associated glycosphingolipids. Cancer Sci. 2018, 110, 1544-1551. [CrossRef] [PubMed]

16. Thurin, J.; Thurin, M.; Herlyn, M.; Elder, D.E.; Steplewski, Z.; Clark, W.H., Jr.; Koprowski, H. GD2 ganglioside biosynthesis is a distinct biochemical event in human melanoma tumor progression. FEBS Lett. 1986, 208, 17-22. [CrossRef]

17. Battula, V.L.; Shi, Y.; Evans, K.W.; Wang, R.Y.; Spaeth, E.L.; Jacamo, R.O.; Guerra, R.; Sahin, A.A.; Marini, F.C.; Hortobagyi, G.; et al. Ganglioside GD2 identifies breast cancer stem cells and promotes tumorigenesis. J. Clin. Investig. 2012, 122, $2066-2078$. [CrossRef]

18. Ly, S.; Anand, V.; El-Dana, F.; Nguyen, K.; Cai, Y.; Cai, S.; Piwnica-Worms, H.; Tripathy, D.; Sahin, A.A.; Andreeff, M.; et al. Anti-GD2 antibody dinutuximab inhibits triple-negative breast tumor growth by targeting GD2(+) breast cancer stem-like cells. J. Immunother. Cancer 2021, 9, e001197. [CrossRef] 
19. Mount, C.W.; Majzner, R.G.; Sundaresh, S.; Arnold, E.P.; Kadapakkam, M.; Haile, S.; Labanieh, L.; Hulleman, E.; Woo, P.J.; Rietberg, S.P.; et al. Potent antitumor efficacy of anti-GD2 CAR T cells in H3-K27M+ diffuse midline gliomas. Nat. Med. 2018, 24, 572-579. [CrossRef]

20. Seitz, C.M.; Schroeder, S.; Knopf, P.; Krahl, A.C.; Hau, J.; Schleicher, S.; Martella, M.; Quintanilla-Martinez, L.; Kneilling, M.; Pichler, B.; et al. GD2-targeted chimeric antigen receptor T cells prevent metastasis formation by elimination of breast cancer stem-like cells. Oncoimmunology 2019, 9, 1683345. [CrossRef]

21. Nakano, J.; Mohan Raj, B.K.; Asagami, C.; Lloyd, K.O. Human melanoma cell lines deficientin GD3 ganglioside expression exhibit altered growth and tumorigenic characteristics. J. Investig. Dermatol. 1996, 107, 543-548. [CrossRef]

22. Ohmi, Y.; Kambe, M.; Ohkawa, Y.; Hamamura, K.; Tajima, O.; Takeuchi, R.; Furukawa, K.; Furukawa, K. Differential roles of gangliosides in malignant properties of melanomas. PLOS ONE 2018, 13, e206881. [CrossRef]

23. Chang, H.R.; Cordon-Cardo, C.; Houghton, A.N.; Cheung, N.K.; Brennan, M. Expression of disialogangliosides GD2 and GD3 on human soft tissue sarcomas. Cancer 1992, 70, 633-638. [CrossRef]

24. Shibuya, H.; Hamamura, K.; Hotta, H.; Matsumoto, Y.; Nishida, Y.; Hattori, H.; Furukawa, K.; Ueda, M. Enhancement of malignant properties of human osteosarcoma cells with disialyl gangliosides GD2/GD. Cancer Sci. 2012, 103, 1656-1664. [CrossRef] [PubMed]

25. Azuma, K.; Tanaka, M.; Uekita, T.; Inoue, S.; Yokota, J.; Ouchi, Y.; Sakai, R. Tyrosine phosphorylation of paxillin affects the metastatic potential of human osteosarcoma. Oncogene 2005, 24, 4754-4764. [CrossRef] [PubMed]

26. Cazet, A.; Bobowski, M.; Rombouts, Y.; Lefebvre, J.; Steenackers, A.; Popa, L.; Guerardel, Y.; Bourhis, X.L.; Tulasne, D.; Delannoy, P. The ganglioside G(D2) induces the constitutive activation of c-Met in MDA-MB-231 breast cancer cells expressing the G(D3) synthase. Glycobiology 2012, 22, 806-816. [CrossRef] [PubMed]

27. Siddiqui, B.; Buehler, J.; DeGregorio, M.W.; Macher, B.A. Differential expression of ganglioside GD3 by human leukocytes and leukemia cells. Cancer Res. 1984, 44, 5262-5265. [PubMed]

28. Merritt, W.D.; Casper, J.T.; Lauer, S.J.; Reaman, G.H. Expression of GD3 ganglioside in childhood T-cell lymphoblastic malignancies. Cancer Res. 1987, 47, 1724-1730.

29. Furukawa, K.; Akagi, T.; Nagata, Y.; Yamada, Y.; Shimotohno, K.; Cheung, N.K.; Shiku, H. G-D2 ganglioside on human Tlymphotropic virus type I-infected T cells: Possible activation of beta-1,4-N-acetylgalactosaminyltransferase gene by p40tax. Proc. Natl. Acad. Sci. USA 1993, 90, 1972-1976. [CrossRef]

30. Okada, M.; Okada, M.; Furukawa, K.; Yamashiro, S.; Yamada, Y.; Haraguchi, M.; Horibe, K.; Kato, K.; Tsuji, Y.; Shiku, H.; et al. High expression of ganglioside GD3 synthase gene in adult T cell leukemia cells unrelated to the gene expression of human T lymphotropic virus type I. Cancer Res. 1996, 56, 2844-2848.

31. Nazha, B.; Inal, C.; Owonikoko, T.K. Disialoganglioside GD2 Expression in Solid Tumors and Role as a Target for Cancer Therapy. Front. Oncol. 2020, 10, 1000. [CrossRef]

32. Perez Horta, Z.; Goldberg, J.L.; Sondel, P.M. Anti-GD2 mAbs and next-generation mAb-based agents for cancer therapy. Immunotherapy 2016, 8, 1097-1117. [CrossRef]

33. Cheung, N.-K.; Kushner, B.H.; Ostrovnaya, I.; Cheung, I.Y.; Kuk, D.; Kramer, K.; Modak, S.; Yataghene, K.; Cheung, N.K. Prolonged progression-free survival after consolidating second or later remissions of neuroblastoma with Anti-G(D2) immunotherapy and isotretinoin: A prospective Phase II study. Oncoimmunology 2015, 4, e1016704.

34. Marx, S.; Wilken, F.; Wagner, I.; Marx, M.; Troschke-Meurer, S.; Zumpe, M.; Bien-Moeller, S.; Weidemeier, M.; Baldauf, J.; Fleck, S.K.; et al. GD2 targeting by dinutuximab beta is a promising immunotherapeutic approach against malignant glioma. J. Neurooncol. 2020, 147, 577-585. [CrossRef]

35. Sarkar, T.R.; Battula, V.L.; Werden, S.J.; Vijay, G.V.; Ramirez-Peña, E.Q.; Taube, J.H.; Chang, J.T.; Miura, N.; Porter, W.; Sphyris, N.; et al. GD3 synthase regulates epithelial-mesenchymal transition and metastasis in breast cancer. Oncogene 2015, 34, 2958-2967. [CrossRef]

36. Vantaku, V.; Donepudi, S.R.; Ambati, C.R.; Jin, F.; Putluri, V.; Nguyen, K.; Rajapakshe, K.; Coarfa, C.; Battula, V.L.; Lotan, Y.; et al. Expression of ganglioside GD2, reprogram the lipid metabolism and EMTphenotype in bladder cancer. Oncotarget 2017, 8, 95620-95631. [CrossRef] [PubMed]

37. Mansoori, M.; Roudi, R.; Abbasi, A.; Abolhasani, M.; Abdi Rad, I.; Shariftabrizi, A.; Madjd, Z. High GD2 expression defines breast cancer cells with enhanced invasiveness. Exp. Mol. Pathol. 2019, 109, 25-35. [CrossRef] [PubMed]

38. Shao, C.; Anand, V.; Andreeff, M.; Battula, V.L. Ganglioside GD2: A novel therapeutic target in triple-negative breast cancer. Ann. N. Y. Acad. Sci. 2021. [CrossRef]

39. Hakomori, S. Structure, organization, and function of glycosphingolipids in membrane. Curr. Opin. Hematol. 2003, 10, 16-24. [CrossRef] [PubMed]

40. Groux-Degroote, S.; Guérardel, Y.; Delannoy, P. Gangliosides: Structures, Biosynthesis, Analysis, and Roles in Cancer. ChemBioChem 2017, 18, 1146-1154. [CrossRef] [PubMed]

41. Cheresh, D.A.; Harper, J.R.; Schulz, G.; Reisfeld, R.A. Localization of the gangliosides GD2 and GD3 in adhesion plaques and on the surface of human melanoma cells. Proc. Natl. Acad. Sci. USA 1984, 81, 5767-5771. [CrossRef] [PubMed]

42. Ohkawa, Y.; Miyazaki, S.; Hamamura, K.; Kambe, M.; Miyata, M.; Tajima, O.; Ohmi, Y.; Yamauchi, Y.; Furukawa, K.; Furukawa, K. Ganglioside GD3 enhances adhesion signals and augments Malignant Properties of melanoma cells by recruiting integrins to glycolipid-enriched microdomains. J. Biol. Chem. 2010, 285, 27213-27223. [CrossRef] 
43. Furukawa, K.; Hamamura, K.; Ohkawa, Y.; Ohmi, Y.; Furukawa, K. Disialyl gangliosides enhance tumor phenotypes with differential modalities. Glycoconj. J. 2012, 29, 579-584. [CrossRef]

44. Haraguchi, M.; Yamashiro, S.; Yamamoto, A.; Furukawa, K.; Takamiya, K.; Lloyd, K.O. Isolation of GD3 synthase gene by expression cloning of GM3 alpha-2,8-sialyltransferase cDNA using anti-GD2 monoclonal antibody. Proc. Natl. Acad. Sci. USA 1994, 91, 10455-10459. [CrossRef]

45. Nagata, Y.; Yamashiro, S.; Yodoi, J.; Lloyd, K.O.; Shiku, H.; Furukawa, K. Expression cloning of beta 1, 4 N-acetylgalactosaminyltransferase cDNAs that determine the expression of GM2 and GD2 gangliosides. J. Biol. Chem. 1992, 267, 12082-12089. [CrossRef]

46. Cheung, N.-K.V.; Saarinen, U.M.; Neely, J.E.; Landmeier, B.; Donovan, D.; Coccia, P.F. Monoclonal antibodies to a glycolipid antigen on human neuroblastoma cells. Cancer Res. 1985, 45, 2642-2649. [PubMed]

47. Zhao, J.; Furukawa, K.; Fukumoto, S.; Okada, M.; Furugen, R.; Miyazaki, H.; Takamiya, K.; Aizawa, S.; Shiku, H.; Matsuyama, T.; et al. Atenuation of Interleukin 2 Signal in the Spleen cells of complex Ganglioside-lacking Mice. J. Biol. Chem. 1999, 274, 13744-13747. [CrossRef] [PubMed]

48. Bhuiyan, R.H.; Kondo, Y.; Yamaguchi, T.; Tokuda, N.; Ohkawa, Y.; Hashimoto, N.; Ohmi, Y.; Yamauchi, Y.; Furukawa, K.; Okajima, T.; et al. Expression analysis of 0-series gangliosides in human cancer cell lines with monoclonal antibodies generated using knockout mice of ganglioside synthase genes. Glycobiology 2016, 26, 984-998. [CrossRef] [PubMed]

49. Yesmin, F.; Bhuiyan, R.H.; Ohmi, Y.; Ohkawa, Y.; Tajimi, O.; Okajima, T.; Furukawa, K.; Furukawa, K. Aminoglycosides are efficient reagents to induce readthrough of premature termination codon in mutant B4GALNT1 genes foumd in families of hereditary spastic paraplegia. J. Biochem. 2020, 168, 103-112. [CrossRef]

50. Hashimoto, N.; Hamamura, K.; Kotani, N.; Furukawa, K.; Kaneko, K.; Honke, K.; Furukawa, K. Proteomic analysis of gangliosideassociated membrane molecules: Substantial basis for molecular clustering. Proteomics 2012, 12, 3154-3163. [CrossRef]

51. Esaki, N.; Ohkawa, Y.; Hashimoto, N.; Tsuda, Y.; Ohmi, Y.; Bhuiyan, R.H.; Kotani, N.; Honke, K. ASC amino acid transporter 2 , defined by enzyme-mediated activation of radical sources, enhances malignancy of GD2-positive small cell lung cancer. Cancer Sci. 2018, 109, 141-153. [CrossRef]

52. Bhuiyan, R.H.; Ohmi, Y.; Ohkawa, Y.; Zhang, P.; Takano, M.; Hashimoto, N.; Okajima, T.; Furukawa, K.; Furukawa, K. Loss of enzyme activity in mutated B4GALNT1 gene products in patients with hereditary spastic paraplegia results in relatively mild neurogical disorders: Similarity with phenotypes of B4galnt1 knockout mice. Neuroscience 2019, 397, 94-106. [CrossRef] [PubMed]

53. Okamoto, K.; Mori, Y.; Komoda, Y.; Okamoto, T.; Okochi, M.; Takeda, M.; Suzuki, T.; Moriishi, K.; Matsuura, Y. Intramembrane processing by signal peptide peptidase regulates the membrane localization of hepatitis $\mathrm{C}$ virus core protein and viral propgation. J. Virol. 2008, 82, 8349-8361. [CrossRef] [PubMed] 